\title{
Managing Change and Master Plans: Machu Picchu Between Conservation and Exploitation
}

Luca Zan and Maria Lusiani, Dipartimento di Scienze Aziendali, University of Bologna, Via Capo di Lucca 34, 40126, Bologna, Italy e-mail: luca.zan@unibo.it

\begin{abstract}
Machu Picchu is among the world's most controversial heritage sites. It represents a case where raising money through ticket sales and other activities, rather than an opportunity to fund site preservation, in fact constitutes a major threat to the survival of the site through overexploitation. Unesco has been very critical in recent decades about the management of Machu Picchu. International pressure resulted in the establishment of two master plans, in 1998 and in 2005. In this paper we investigate in depth the contents and rhetoric of the two plans, comparing changes in the two different versions, and linking the change in planning attitude to actual changes taking place in the site. This is also an opportunity to open a discussion on the interdisciplinarity of master plans in heritage sites.
\end{abstract}

Résumé: Machu Picchu est l'un des sites patrimoniaux les plus controversés au monde. II représente un cas où la collecte de fonds par la vente de billets et d'autres activités, plutôt que la possibilité de financer la préservation du site, constitue, en fait, une menace majeure pour la survie du site à travers la surexploitation. L'Unesco a été très critique ces dernières décennies sur la gestion de Machu Picchu. La pression internationale a abouti à la création de deux plans directeurs, en 1998 et en 2005. Dans cet article, nous étudions en profondeur le contenu et la rhétorique des deux plans, en comparant les changements dans les deux versions différentes, et en reliant les changements d'orientation du programme aux réels changements ayant lieu sur le site. C'est aussi l'occasion d'ouvrir un débat sur l'interdisciplinarité des plans directeurs sur les sites du patrimoine.

Resumen: Machu Picchu es uno de los lugares patrimonio de la humanidad más controvertidos del mundo. En su caso, la recaudación de dinero con la 
venta de tickets y otras actividades no solo no está sirviendo para financiar la preservación de la zona, sino que constituye una grave amenaza para su supervivencia debido a la sobreexplotación. En las últimas décadas la Unesco ha sido muy crítica con la gestión del Machu Picchu. La presión internacional ha conseguido la aprobación de dos planes maestros, en 1998 y en 2005. En el presente trabajo investigamos a fondo el contenido y la retórica de los dos planes, comparando las diferencias de las dos versiones y asociando el cambio de actitud a los cambios reales que tienen lugar en el sitio. También brinda una oportunidad para abrir un debate sobre el carácter interdisciplinar de los planes maestros en los lugares patrimonio de la humanidad.

\section{KEY WORDS}

Management, Planning, Managerial rhetoric, Master plan, UNESCO sites

\section{Introduction}

This paper investigates the process of change at Machu Picchu in the last years through analysis of the two master plans prepared for the site, in 1998 and 2005 respectively.

This type of research has several elements of interest at different levels of detail. At a general level, the issue of plans has become increasingly important in the heritage field as professional entities and international agencies foster the adoption of Master Plans across the globe. According to the UNESCO Convention of 1972 and its operational guidelines, inclusion of a site in the World Heritage List requires measures of conservation and management. To that end, the adoption of managerial and planning tools is a fundamental requirement for all world heritage sites (e.g. Ringbeck 2008; for a comprehensive bibliography on management plans applied to World Heritage sites see ICOMOS, 2010).

Other disciplinary traditions are also acting in a similar direction: the diffusion of management discourse to arts and heritage institutions brings with it a specific type of planning within the discourse of management: that is to say the logics and tools of business plans.

Despite the increasing reference to plans and planning, given the multidisciplinary nature of heritage and the various disciplines involved-from urban planning, to regional planning, to business and organizational theory-it is hard to find a clear presentation of the state-of-the-art in this set of similar (yet not the same) tools and approaches. Despite some similari- 
ties to that of management, the discourse of planning has a parallel and to some extent independent genealogy, probably linked to its adaptation to different objects and topics (the urban fabric, regional issues, internal organizational aspects) and their complex natures.

Scholarly literatures are also divided, and rarely acknowledge reciprocal influences or share epistemological and operational issues. For instance, despite the development of tools that are still in use, such as the SWOT analysis developed in the "golden age" of strategic planning in the 1960s (Learned et al. 1969; for an overview see Friesner 2011), a more skeptical approach to the development of the research about the nature of organizational decision making emerged, along with the increasing relevance of the notion of bounded rationality (Simon 1947, 1991; March 1988). Starting from the 1970s a huge debate on the meaning and usefulness of planning has been carried out in the management field, even in respect to profitseeking entities (Normann 1977; Mintzberg 1978; Pettigrew 1987; for a summary see Zan 1990). What is curious to notice is that in the heritage field, there has been no such discussion on "the rise and fall of strategic planning", to use Mintzberg's (1994) words.

In this context, understanding how plans are carried out in a specific important case-like Machu Picchu—can provide an in-depth understanding of how the composite disciplinary status of plans and planning is translated into actual practices. Even describing the contents of the two plans is not an easy or a simplistic issue, given the inner complexity of planning discourse: what are the major differences in terms of structure, contents, and rhetoric between two plans? And what is the relationship between these features and the actual process of change? To what extent planseven master plans-really matter is a serious research question. At a general level—using the case of Machu Picchu in a merely instrumental way - the focus on different ways of conceiving plans for the same site, stressing their differences in substantive and rhetorical aspects is one of the contribution of this article (to put provocatively, even for a reader not concerned with Machu Picchu itself).

At the specific level, however, few cases are more challenging than Machu Picchu. One of the most controversial World Heritage sites, it has been under scrutiny by UNESCO since the 1990s, with the constant threat of being put on the list of World Heritage sites in danger, and a particularly conflict-ridden tension between conservation and exploitation (Burger and Salazar 2004; Regalado-Perzua and Arias-Valencia 2006; Silverman 2006; Reinhard 2007; Higueras 2008).

Since its discovery and until the late 1990s (i.e. even after its institutionalization as a "protected natural area" by the government of Peru in 1981 and, subsequently, as a "World Heritage Site" by UNESCO in 1983) only sporadic conservation interventions had been undertaken, without the 
framework of an integrated action plan. Over time, therefore, the issue of management arrangements and planning mechanisms for the preservation of the Sanctuary have become of greater concern to UNESCO. Since 1996 UNESCO has examined the state of conservation of the Sanctuary at various sessions. In UNESCO's reports on the state of conservation of Machu Picchu particular stress is put on the urgency for the Peruvian government to adopt adequate management arrangements and comprehensive master planning for the Sanctuary.

In response to UNESCO's concerns, the government of Peru and the institutions in charge of the management of the Sanctuary have, since the late 1990s, become gradually involved in the process of formulating, adopting and implementing specific planning tools (indeed, more than "formulation" or "implementation", the term "formation" should be used, see Mintzberg 1978). This marked the beginning of a culture of "managing by plans" at the Sanctuary. So far two plans have been applied, the first one for the period 1998-2003 and the second one in 2005 (still active). The two documents deeply differ in their structure, their intentions, and ability to be an effective driver for change. They reflect two very different orientations and "worldviews" in terms of cultural policies for the protection and use of the site.

\section{Background and Methodology}

This study is based on field research developed in two different visits: one in May 2007, wherein one of the authors was doing participant observation during the mid-term visit of a World Bank delegation within the Project of Rehabilitation of the Vilcanota Valley; the second in May-June 2008 at Cusco and Machu Picchu, with the explicit aim of developing a clinical case study on the management of heritage at Machu Picchu. About 30 in-depth interviews were been carried out, along with the analysis of a wide range of documents (legislation; press articles; literature on Peru's political/administrative system; UNESCO, World Bank and Icomos reports on Machupicchu; and other internal documents and reports).

As management scholars, we examine the situation with a particular focus on resources allocation and how attention is addressed toward "getting things done" (one of the more interesting perspectives in management studies; see March 1988). In particular, in this paper we are looking at how the two master plans intervene in the process of change at Machu Picchu, deconstructing them through content analysis. If we had to position our approach within management studies, our methodological preferences would be related to decision-making debates, strategic change, and more specifically understanding of management as discourse and rhetoric (for a 
more precise epistemological positioning the reader could refer to Zan 2006).

In this paper, we focus on the content analysis of the two master plans, as part of our broader field research, another aspect of which is provided in another paper (Zan and Lusiani, forthcoming). In order to share aspects of the context with the reader, some of the basic features of Machu Picchu will be summed up in the following section (and see Zan and Lusiani, forthcoming, for a deeper analysis). The first important element for understanding the master plans is the complex institutional fragmentation that characterizes the site. Machu Picchu-or better the Historical Sanctuary of Machu Picchu, referred to as "HSM" hereafter-is both a cultural and natural UNESCO site. According to the administrative rules of Peru, this implies that it is subject to two different ministries, the Ministry of Education (through the Instituto Nacional de Cultura, INC), and the Ministry of Agriculture (through the Instituto Nacional de Recursos Naturales, INRENA). Given policies of de-centralization, however, it is the local branch of

Box 1 Perù-the political/administrative context (based on Giugale et al. 2006)

The Peruvian public administration as a whole has undergone a major transformation process in the latest years. From a political point of view characterized as an authoritarian regime, if not fascist, the Fujimori era had important consequences also at the administrative level. If corruption and illegal behaviours marked the end of Fujimori itself, at the end of the period one of the major elements of collapse of the State was its high level of centralization, perhaps the most centralized country in America Latina (p. 757)

Hence, the main driver of the change in the following period has been the orientation towards the "modernization of the State", for a more efficient, more rational, more transparent and controlled public administration. Since the early 2000's all public institutions and Ministries underwent a process of administrative, financial, productive and fiscal decentralization (Ley 27783/2002, "Ley de Base de Descentralización”)

The logic of the reform was to simplify the bureaucratical procedures and to better address the needs of the whole territory by creating and empowering regional and local autonomies. Indeed, it is by this law that the national territory was divided into regions, departments, provinces and districts/municipalities. They were accorded political, administrative and financial autonomy, while the central government preserved the supreme role of control of the territory and of definition of the general policies in the name of the basic principle of the unity of the Nation. For instance, the financial autonomy of the peripheral organs allows them to generate and administer their own resources but only within the framework of the national policy documents and of the annual budget laws (the central government will still define the economic structure of the Country). In sum, the decentralization reform was aimed to meet both more flexibility, more autonomy and more transparency in the flow of actions and decisions at all levels of the public sector

The process is still in spin. Major areas in the reform of the State itself are concerned: 1. A new law on Executive Power defining the role of central and local government; 2. Fiscal reform, with reform o the Fiscal administration and issues of monitoring and evaluation; 3. the quality of public expenditures, relating to issue such as human resources, procurement, public investments, decentralization 
INC (INC-Cusco) that is in charge of the site for the cultural aspects (see Box 1 for a very short recap of decentralization policies in Peru).

To make things particularly complicated, there is a third major actor involved: the municipality of Aguas Calientes, which was renamed Machu Picchu Pueblo in the past decade to be more "marketable". Machu Picchu Pueblo is a tourist city, explicitly built and devoted to the exploitation of tourism at the HSM, and explicitly addressed by UNESCO as one of the major problems for its preservation. The city is outside the control of any urban plan, which has led to construction in prohibited areas, despite landslide risks, and without any respect for the preservation of the area just below the entrance of the park ${ }^{1}$. Most of the local population is actually not local, but rather come here for few years to work in tourism, and then move back home. Strikingly, the municipality of Aguas Calientes is associated in the management and governance of the site-a problem itself for the preservation of the HSM.

Moreover, seen from Cusco, HSM is just one of the many heritage sites under their responsibility, with many other sites all along the Vilcanota Valley and the surroundings of Cusco, which has several implications. On the one hand, the UNESCO site (HSM) is just a subsidiary of one of the bodies in charge of it (INC-Cusco). This partial organizational overlapping - there is not one but three organizations involved in the management of the UNESCO sites, yet each is only partially involved-is likely to create continuous problems and conflicts in the area. On the other hand, in terms of human resources, only 186 people work in the HSM Archaeological Park out of the 1,326 staff working at INC-Cusco (not including projectbased employees). Also, in terms of human resources, it should be noted that only 123 people have permanent positions (out of the total of 2,751, including project-based employees).

Third, some information on visitors can be summed up from our research. In 2007 about 800,000 people visited the HSM (Figure 1), 142,000 using the Inca trail, making HSM one of the most profitable sites in the world. The entrance fee is about 40 US\$, the train to get to Aguas Caliente costs 90-130 US\$, and the bus from Aguas Calientes to the Park $(6 \mathrm{~km})$ costs 9 US\$. This illustrates two interesting elements in the economics of the site. The "externalities" such as the rents provided to private companies following the generous outsourcing policies in the 1990s are evident (the train was privatized, as was the hotel just in front of the entrance of the park, as well as contracts with local bus companies). However, although only one third of the money spent by the tourist is kept by public entities because of privatization, the total of 800,000 visitors still means that the state receives a significant income from the site.

This leads to a fourth element to keep in mind: the nature of the business model characterizing HSM and INC-Cusco (see Figure 2). In 2007, 


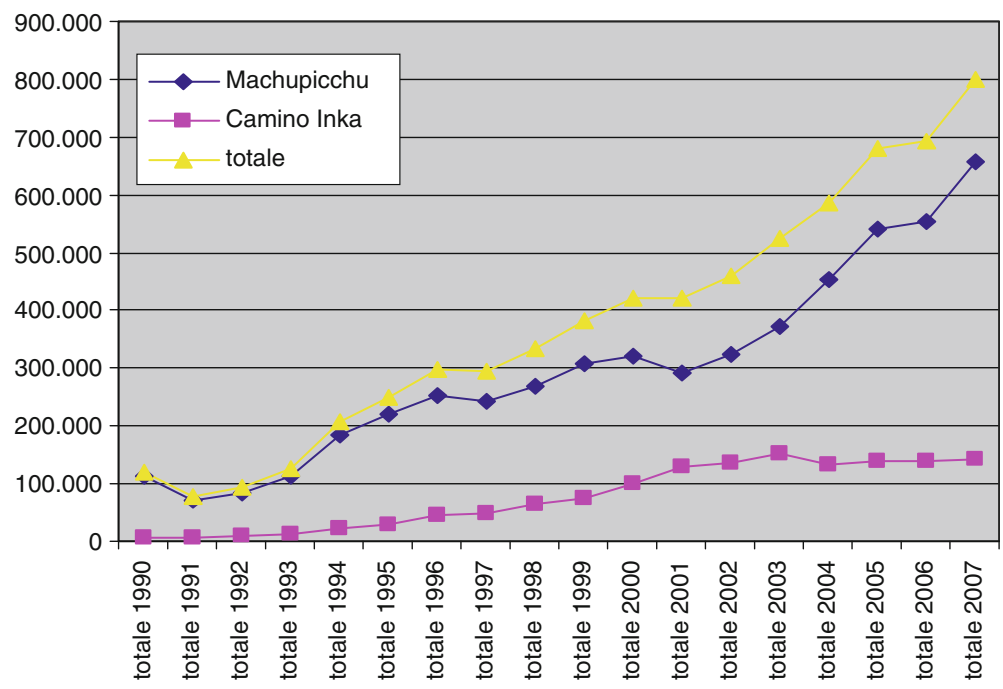

Figure 1. Visitors (1990-2007)

out of 87.7 million Nuevo Soles 6.2 million (about 7\%) were transferred to the municipality of Aguas Calientes, another 12.2 million (15\%) to the Qhapaq Nan project in Cusco and another 12.2 million to the Qhapaq Nan project in Lima. While the latter reflects an explicit cultural policy set up at the beginning of the 2000s as part of the international development project on Main Andean Roads (http://whc.unesco.org/en/qhapaqnan/), the former underlines the bargaining power of the local government in sharing benefits (a history of blocking access to the site is here involved). For its part, INC-Cusco is almost totally self-funded by HSM ticket revenues, with very marginal inflows from Lima. About 69.3 million Soles remain for the management and conservation of the various sites in the Cusco area: in this sense HSM generously subsidizes the other sites in the Vilcanota Valley and Cusco.

Finally, as a methodological note, a specific warning is needed in reading Figure 2 (and more in general financial statements) for the ICN-Cusco: surpluses presented do not have the usual meaning of savings, as in "normal" income statements. In fact, in order to combat corruption, a new administrative system was set up in the country since 2000 (Sistema Nacional de Inversión Pública [SNIP], see Box 2), which has since 2003 also been applied to the heritage sector, with serious implications for accounting representation and indeed also for the ways in which money is spent. In this system, all investments that use public resources have to be approved in Lima. Significant for our study, all conservation projects are 


\begin{tabular}{|c|c|c|c|c|c|c|}
\hline & 2002 & 2003 & 2004 & 2005 & 2006 & 2007 \\
\hline MACHU PICCHU & $17,075,909.10$ & $18,412,301.02$ & $23,660,344.20$ & $32,140,170.25$ & $43,188,768.00$ & $61,938,130.50$ \\
\hline CAMINO INKA & $10,536,236.50$ & $10,486,122.60$ & $9,492,519.75$ & $11,013,759.97$ & $12,862,875.75$ & $15,352,097.25$ \\
\hline MUSEO DE SITIO DE MAPI & & & & & $119,870.00$ & $201,182.70$ \\
\hline MUSEO DE SITIO DE CHINCHERO & & & & & $2,583.00$ & $4,086.50$ \\
\hline TIPON & $11,629.00$ & $17,458.00$ & $19,942.00$ & $23,094.00$ & $30,303.50$ & $37,973.50$ \\
\hline TARAWASI & $3,828.00$ & $5,326.00$ & $4,826.00$ & $4,486.00$ & $4,398.00$ & $6,910.50$ \\
\hline RAQCHI & $64,041.00$ & $188,852.00$ & $265,326.00$ & $367,660.50$ & $411,599.00$ & $495,203.00$ \\
\hline MORAY & $48,438.00$ & $97,856.00$ & $126,557.00$ & $174,980.50$ & $188,616.00$ & $270,672.50$ \\
\hline PIKILLAQTA & $4,964.00$ & $6,912.00$ & $7,717.00$ & $8,619.50$ & $9,261.50$ & $14,968.50$ \\
\hline CHOQUEQUIRAO & & $2,812.00$ & $34,426.00$ & $37,012.00$ & $43,464.00$ & $54,608.50$ \\
\hline HUCHUY QOSQO & & & & & $18,927.00$ & $29,478.00$ \\
\hline BOL. TURISTICO (OFEC) & $2,341,951.18$ & $2,514,342.87$ & $3,022,158.03$ & $6,353,544.68$ & $7,006,017.06$ & $8,657,564.69$ \\
\hline VACACIONES UTILES & $8,703.00$ & $2,714.00$ & 0.00 & 0.00 & 0.00 & 0.00 \\
\hline ING DIV ANULAC. & & 979.36 & $9,670.09$ & $21,872.72$ & 133.41 & 0.00 \\
\hline VENTA BIENES & $20,537.20$ & $8,545.30$ & $26,315.00$ & $30,720.40$ & $55,732.42$ & $39,758.75$ \\
\hline INTERESES BANCARIOS & $4,477.97$ & 0.00 & 0.00 & 0.00 & $3,298.98$ & 0.00 \\
\hline ALQUILER & $40,848.80$ & $3,494.80$ & $11,092.00$ & $2,860.00$ & $2,112.00$ & $59,429.20$ \\
\hline DI. BANCARIO & $873,848.00$ & $565,000.00$ & $177,500.00$ & 277.95 & 0.00 & $4,150.68$ \\
\hline MULTAS Y SANCIONES & & & $237,875.58$ & $232,080.02$ & $162,190.03$ & $100,717.46$ \\
\hline BIENES BAJA & & & & & & $90,408.04$ \\
\hline OTROS SERVICIOS & $142,298.25$ & $131,069.74$ & & $234,234.52$ & $330,411.38$ & $327,269.27$ \\
\hline OTHER & $3,565,564.40$ & $3,545,362.07$ & $3,943,404.70$ & $7,491,442.79$ & $8,388,917.28$ & $10,394,381.79$ \\
\hline Income before transfers & $31,177,710.00$ & $32,443,785.69$ & $37,096,268.65$ & $50,645,373.01$ & $64,440,561.03$ & $87,684,609.54$ \\
\hline Amount transferred to the Municipality * & & $17,276.40$ & $2,380,298.75$ & $3,214,017.03$ & $4,318,876.80$ & $6,193,813.05$ \\
\hline Income before transfer to QN & $31,177,710.00$ & $32,426,509.29$ & $34,715,969.90$ & $47,431,355.98$ & $60,121,684.23$ & $81,490,796.49$ \\
\hline $70 \%$ INC-CUSCO & & & $24,301,178.93$ & $33,201,949.19$ & $42,085,178.96$ & $57,043,557.54$ \\
\hline $15 \%$ QHAPAQ NAN CUSCO & & & $5,207,395.49$ & $7,114,703.40$ & $9,018,252.63$ & $12,223,619.47$ \\
\hline $15 \%$ QHAPAQ ÑAN NACIONAL & & & $5,207,395.49$ & $7,114,703.40$ & $9,018,252.63$ & $12,223,619.47$ \\
\hline TOTAL INCOME of INC Cusco & $31,177,710.00$ & $32,426,509.29$ & $29,508,574.42$ & $40,316,652.58$ & $51,103,431.60$ & $69,267,177.02$ \\
\hline Administrative expenditures & $2,996,422.63$ & $2,872,810.44$ & $3,249,309.52$ & $3,338,492.49$ & $3,679,415.57$ & $4,436,630.10$ \\
\hline Maintenance & $5,507,163.89$ & $8,278,951.89$ & $11,923,109.95$ & $13,630,571.85$ & $16,868,647.41$ & $21,438,247.38$ \\
\hline Investment projects & $11,499,934.30$ & $11,903,728.64$ & $13,760,308.14$ & $18,663,552.63$ & $17,302,404.52$ & $15,805,948.93$ \\
\hline TOTAL EXPENDITURES of INC-Cusco & $20,003,520.82$ & $23,055,490.97$ & $28,932,727.61$ & $35,632,616.97$ & $37,850,467.50$ & $41,680,826.41$ \\
\hline SURPLUSTDEFICIT (Income before transfers & $11,174,189.18$ & $9,388,294.72$ & $\frac{80,303,1617.04}{8,163,541.04}$ & $15,012,756.04$ & $26,590,093.53$ & $46,003,783.13$ \\
\hline SURPLUS/DEFICIT (Income-Expenditures) & $11,174,189.18$ & $9,388,294.72$ & $575,846.80$ & $4,684,035.61$ & $13,252,964.10$ & $27,586,350.61$ \\
\hline
\end{tabular}

Figure 2. INC-Cusco financial results

considered investment projects, and are thus subject to this procedure. From a numerical point of view, more than surplus/saving, what is presented at the bottom line in Figure 2 is a gross margin $(52.5$ or $31.5 \%$ of the total income, before or after transfer respectively) that is used for "investments" in conservation.

\section{Managing the HSM With Plans: Continuity and Change}

In this section an in-depth description of the two master plans is provided, with a preliminary interpretation and some direct comments. A comparison and final assessment will be provided in the following discussion in "Background and Methodology" section.

\section{A First Planning Effort: Plan Maestro 1998-2003}

Mainly in response to UNESCO's requests, in 1998 the government of Peru under President Fujimori produced a first planning document for the HSM (Plan Maestro del Santuario Historico de Machu Picchu 1998. For a 


\section{Box 2 The functioning of the National System of Public Investments (SNIP)}

The main purpose of the SNIP is to certify the quality of public investment projects through the establishment of a shared standard for both elaborating and evaluating those projects. A public investment project (as defined by the Law that creates the SNIP, Ley 27293/2000) is promoted by a public administration or other public entity; can be promoted by third parties when a public government or other public entity is in charge of the maintenance and current expenditure following the initial investment; is limited in time; is partly or totally funded by public resources; is linked to the goals of the public administration or other public entity that promotes it (basically: the creation/extension/improvement/recover of a public service or good); does not concern maintenance and current expenditures

A "by-product" of the SNIP is also the instilling of a planning attitude and a sense of responsibility for the use of public resources in the mindset of public entities (in order to move on from a culture of waste of money, lack of planning or even corruption). Essentially, the SNIP regulates the life cycle of a project from the birth of an idea to its implementation. Before the introduction of the SNIP no formal procedure for the control and assessment of public investment projects existed. Now every single public project has to obtain the approval by the pertinent technical organ on behalf of the government before it is executed. The organs involved in the SNIP process are:

the general directorate for the multi-annual planning for the public sector, belonging to the Ministry for Finances (the formal responsible for the process);

the OPI-Oficina de Planificacion y Inversiones (who evaluates the project and declares its feasibility);

the proposing entity (who formulates the project);

the executive entity (who runs the project)

The assessment focuses exclusively on the quality of the project in its merit and method on the base of a standard system of principles and regulations. In no way it is a deliberation on the allocation of public resources for those projects, nor a definition of investment priorities (the SNIP is not a system to apply for public funding: it is a system to certify the quality and feasibility of public projects whose public funding is already deliberated)

The life cycle of a public investment project as dictated by the SNIP includes a phase of preinvestment, investment and post-investment; for every phase the proposing entity is obliged to prepare specific standard documents. More in detail:

in the pre-investment phase a project is submitted to the OPI; the OPI evaluates it and within 30 to 45 days either releases a declaration of feasibility (when the public investment is socially rentable, sustainable and compatible with the national policies), requires revisions, or rejects the project. In this phase three documents may be needed (the "perfil"-basic document, always needed -, the "pre-feasibility study" and the "feasibility study"), according to the amount of the investment (the higher the investment, the more documents with more detailed plans and estimates are required)

In the investment phase an approved project gets implemented by the executive entity. In the first place, the entity has to produce a "technical expedient" (a detailed, executive project) in accordance with the parameters approved in the pre-investment phase. In the second place, the entity has to monitor the implementation of the activities and inform the OPI about any modification

Finally, in the post-investment phase a project is concluded: the executive entity carries on maintenance and operational work and an evaluation of the impacts of the investment should be undertaken by an independent agency

Interestingly enough, the decentralization processes concerned the SNIP as well: since 2007 the OPIs (formerly located at the central government level) are established within the regional and local governments. As a consequence, the regional and local governments become direct responsible of the control of the quality of any public investment projects within their jurisdiction 


\section{Box 2 continued}

The introduction of the SNIP is a very recent phenomenon, it is being gradually applied and improved. However, the effects of its introduction are already visible in the public administration. Apparently the SNIP is positively welcomed by the professionals of the proposing and executive entities: in their opinion the system is actually bringing order and transparency to public expenditure, is reducing chaos, waste of money and eternal bureaucratical procedures (interviews with INC-Cusco professionals). Yet, just like all standardized systems, it brings order and rigor to detriment of flexibility; in fact, the SNIP at its present state (the documentation it requires, the parameters it entails, the competences of the evaluators) is mainly thought for infrastructure/ building public investment projects and is, for instance, less easily applicable to the cultural field

critical view see Martorell Carreño 2004). From then on, interventions in the Sanctuary could not be undertaken in isolation, but had to fit the framework of the Master Plan. Per UNESCO recommendation, a Management Unit (or UGM: Unidad de Gestión de Machu Picchu) for the implementation of the Plan was established in 1999 by a governmental act.

The new Master Plan was formulated under the supervision of INC and INRENA by a professional team (composed by two experts in planning and management of protected natural areas, an archaeologist, and a lawyer), with the contribution of a number of governmental and non-governmental organizations in two stakeholder workshops.

The outcome of such a major consultative process was a 337-page-long document divided into four 90-page chapters plus appendixes (Figure 3$)^{2}$. If management is a matter of addressing attention, understanding the managerial aspects and implications of the Plan requires a reconstruction of where and how attention was addressed in the process. Therefore, we will here examine the contents and the rhetoric of each section of the Plan.

\section{The Historical Sanctuary of Machu Picchu}

In this introductory section, the values contributing to the outstanding value of the HSM are made clear. The borders, extent, and location of the Sanctuary are then described and a first list of objectives is presented.

In describing the values of the site, the Plan opens with a statement on how cultural and natural values overlap and interact, and how the ecological, historical, archaeological, religious, and spiritual interests are inseparable. Besides the scientific interest of the place, the attractiveness of the site for tourists is made clear too. ("a site of interest for scientists" and "a destination sought by tourists all over the world", p. 5).

As for the objectives presented in this introductory section, it should be noted that: 


\begin{tabular}{|l|r|}
\hline Chapter & page \\
\hline $\mathbf{1}$ Historical Sanctuary of Machupicchu & $\mathbf{5}$ \\
\hline General description & 5 \\
\hline Location and boundaries & 7 \\
\hline Objectives & 7 \\
\hline $\mathbf{2}$ & The Plan Maestro for the HSM \\
\hline $\mathbf{3}$ Outcomes of the workshop on the vision for the HSM (SWOT analysis) & $\mathbf{2 2}$ \\
\hline Strengths & 22 \\
\hline Opportunities & 24 \\
\hline Threats & 25 \\
\hline Weaknesses & 26 \\
\hline Strategy for the conservation and management of the HSM & $\mathbf{2 8}$ \\
\hline Strategy for the preservation of the natural heritage and landscape & 33 \\
\hline Strategy for the preservation of the cultural heritage & 36 \\
\hline Zoning & 39 \\
\hline Strategy for the access to the Sanctuary and other infrastructures & 65 \\
\hline Railway & 68 \\
\hline Helicopters & 69 \\
\hline Roads & 70 \\
\hline Cableway & 71 \\
\hline Inca trails & 72 \\
\hline Hydroelectric central and energy transmission & 73 \\
\hline Strategy for tourism and leisure & 74 \\
\hline Carrying capacity & 75 \\
\hline Services and infrastructure for the visitors & 77 \\
\hline Hotels & 78 \\
\hline Information and visitor centres & 79 \\
\hline Communication & 80 \\
\hline Concessions and contracting out of visitor services & 80 \\
\hline Strategy for the institutional coordination, information flows, functions and & \\
\hline responsibilities & 81 \\
\hline Strategy for permanent planning development & 83 \\
\hline Strategy for the physical and juridical consolidation of the HSM & 84 \\
\hline Stratefy for the sustainable development of Aguas Calientes & 86 \\
\hline Strategy for funding & 88 \\
\hline References & $\mathbf{9 0}$ \\
\hline Appendix & $\mathbf{9 1}$ \\
\hline
\end{tabular}

Figure 3. Plan Maestro 1998-summary

- they are explicitly inspired by the national legislation on "protected natural areas," 3 while no mention is made to the UNESCO Convention and its principles;

- to a certain extent the objectives are affected by a "naturalistic bias": attention is given both to archaeological research and conservation issues and to naturalistic/landscape conservation issues ("objective 1: to protect the natural and landscape environment, as well as archaeological and cultural heritage"p. 8), but more emphasis is given to the 
latter ("objective 2: "to preserve the natural and semi-natural ecosystems, as well as the native fauna and flora, also taking care of its ecological restoration when needed", ibid.);

- however, the naturalistic and the cultural-historical aspects cannot be separated either conceptually, nor in terms of conservation actions (e.g. flora and fauna are at a large extent connected to religion, the ecosystems are associated to the ancient Inca agricultural practices, and so on);

- tourism as a vehicle for socio-economic development of the region is a central topic-two objectives out of seven deal with the issue of sustainable tourism;

- finally, attention is focused on visitors and the quality of their cultural/educational experience.

\section{The Master Plan for the HSM}

In this short section (seven pages plus exhibits) a rough description of phases and actors involved in the formulation of the Master Plan is provided. To our knowledge, no economist or management expert was involved in this phase in 1998, which is also reflected in the document by the absence of any kind of financial projections. Indeed the reader is left with the impression that the plan is superficial, made up of guidelines or intentions rather than actual, concrete action plans, and delegates specific decision-making to the Management Unit and to a future time.

\section{SWOT Analysis}

The third section of the Master Plan (six pages) outlines an analysis of strengths, weaknesses, opportunities and threats (swot) of the HSM (for details see Figure 4). Despite the strategic management handbook connotations of such an analysis, some inconsistencies ${ }^{4}$, and the rhetorical and somewhat empty sound of certain parts of $i^{5}$, it is anyway possible to remark where attention is mainly addressed.

On the side of weaknesses and threats, it should be noted that the problem of Aguas Calientes and its uncontrolled, chaotic urban growth is acknowledged in the Plan. It is mentioned among other problems of lack of rural and urban planning, but is not presented as the central problem here (as UNESCO claims in its documents). However, much attention is given to the issue in the following sections of the Plan. According to the analysis, the major weaknesses of the HSM are in organizational aspects: lack of coordination, lack of planning and control systems, information dispersion, poor managerial capabilities 


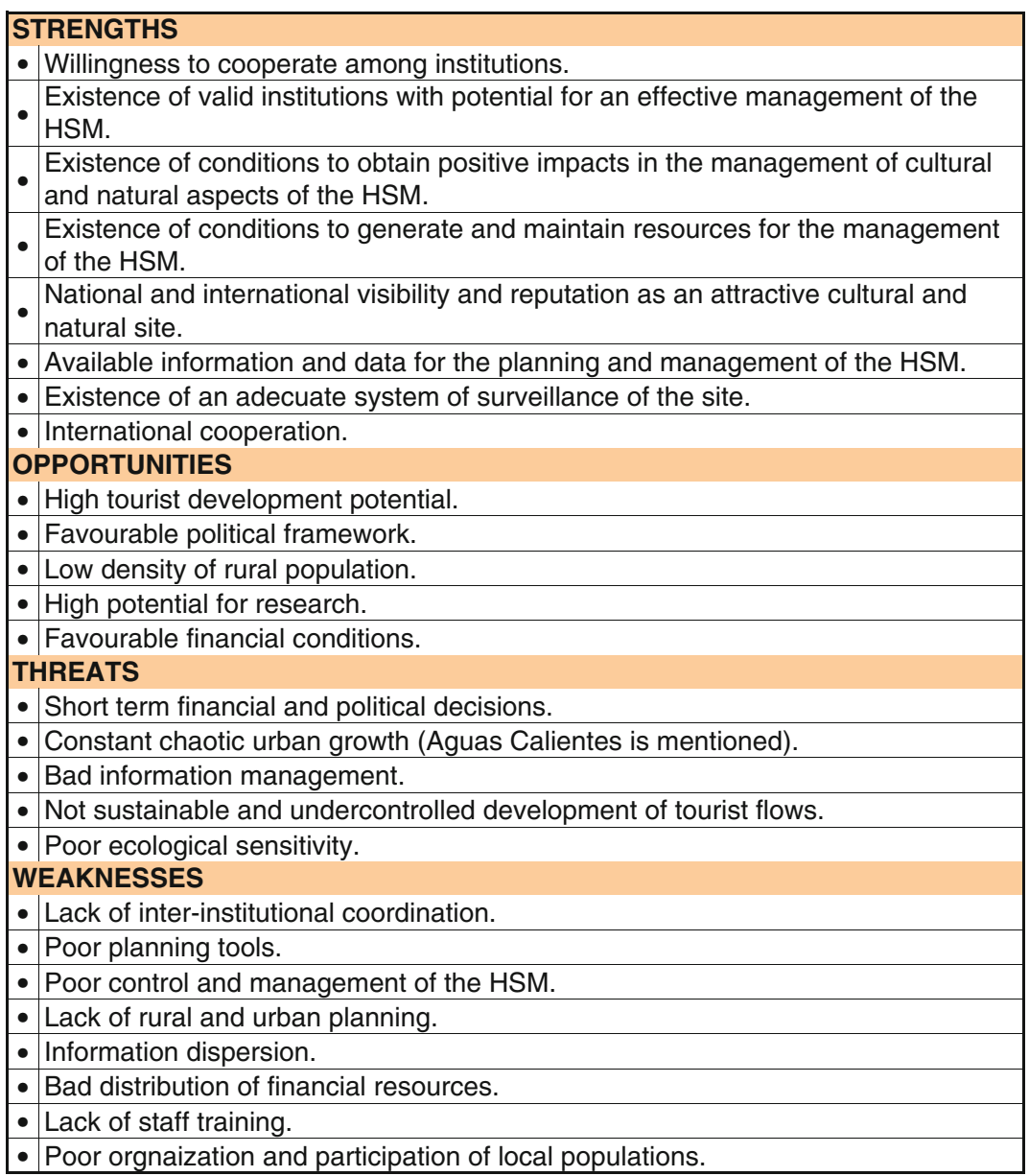

Figure 4. Plan Maestro 1998-SWOT analysis

On the side of strengths and opportunities, the international visibility, and the ability to generate and attract resources are well highlighted.

Strategy for the Conservation and Management of the HSM

This is the central section of the Master Plan (about 60 pages long) where the guidelines for future action are defined. It is stated that the Master Plan is indeed a "strategic" Master Plan, involving the statement of a clear "vision" for the HSM, the formulation of strategies, the definition of 
objectives and related "strategic lines" (lineamientos estratégicos, a type of operational objective).

The vision of expected achievements in 10-year-time (1998-2008) is made explicit through a list of 16 expected outcomes concerning organizational aspects (creating a good management, planning and control system), efficiency (financial sustainability) and effectiveness (natural and cultural heritage conservation targets, high quality offerings to visitors, and involvement of the local population: pp. 29-32 of the Plan). The unusually lengthy discussion however does not end up with any vision statement.

What follows is the presentation of 10 strategies (Figure 5), each one expanded into its specific objectives, strategic lines (lineamientos) and, in one case, methodology.

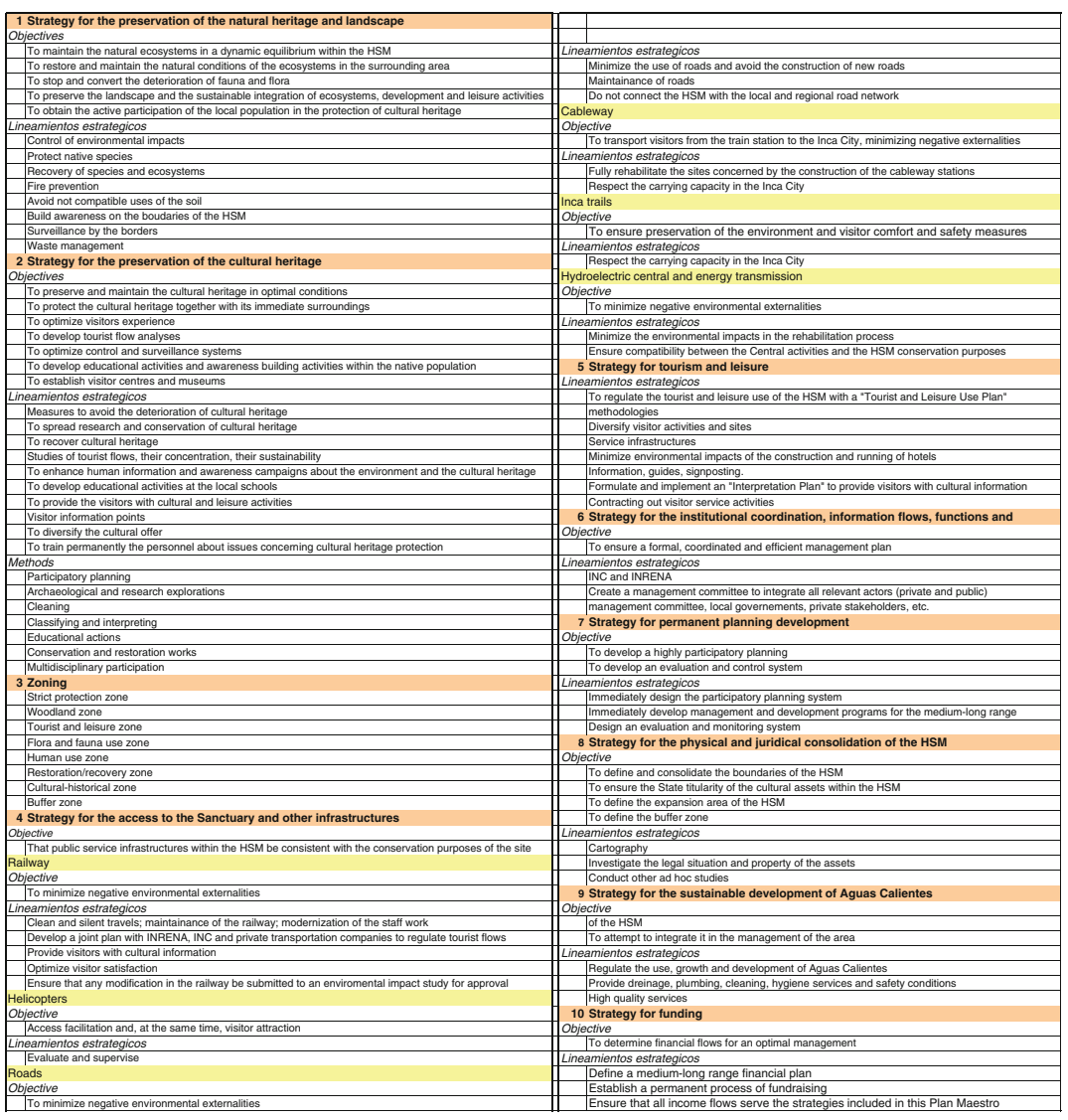

Figure 5. Strategies in Plan Maestro 1998 
In terms of rhetoric, it should be noted that the fundamental reference for the definition of the strategies is the above-mentioned national legislation on the protected natural areas. Only secondary reference is made to the international principles of UNESCO and UICN. Moreover, one could expect here an outline of more concrete, operational forms of planning, but the strategies and their objectives remain at a general level (rather a declaration of intentions), without substantial differences, just a further degree of specification, from the general objectives of the opening section.

In terms of contents, the first strategies seem to adopt a "normal" approach to the preservation of the site: preservation of nature and landscape is Strategy 1; preservation of cultural heritage is Strategy 2; and zoning is strategy 3. Some comments can be made, however, on less "conventional" features of the plan.

A specific attention is devoted in Strategy 5 to tourism and leisure development. In this chapter a discussion of the issue of carrying capacity is developed (pp. 74-77, for 865 words): curiously enough, what is presented is a mere abstract discussion, where not a single number is provided.

One of the main finalized strategies is the creation of a management unit (UGM) for the Sanctuary (Strategy 6). However, only the general functions for the UGM are outlined ${ }^{6}$, delegating all organizational issues to the discretion of the UGM itself, once it is established. There is no structure proposed, and no projection of human resource needs or resource allocation. It is probably here that the authors lost the opportunity to make a strong decision about a univocal authority for the UGM. Instead, a polycentric solution is evoked (direction by INC, INRENA and Aguas Caliente) which implies inter-institutional cooperation, despite the inter-institutional conflicts and lack of coordination had been repeatedly pointed out as one of the major weaknesses of the HSM. This is a weak organizational solution indeed.

As for the "permanent development and planning" (Strategy 7), it should be remarked that-here again — reference is made exclusively to the national criteria for the management of protected natural areas. It is stated that the concept of strategic planning and participatory planning (a coordinated planning process involving all the relevant stakeholders), also referred to as "modern planning", became rooted in the national tradition in the 1970s and expanded up to the 1990s (p. 83). Hence a sort of planning mentality pre-existing the intervention of UNESCO seems to be implied, even though no integrated, systematic and planned intervention had previously taken place in the protected natural areas of the HSM.

Aguas Calientes is as a problem in the Master Plan 1998: a whole strategy (Strategy 9) is dedicated to the issue. The overlap between the territory of the HSM and the jurisdiction of the municipality of Aguas Calientes, the chaotic and unregulated urban growth, the negative image for visitors, 
the lack of adequate services, pollution, solid waste and the contamination of the river, the exposure to landslides and flood threats are all acknowledged as main problems of the area. Nevertheless the strategy for Aguas Calientes remains mainly a declaration of concerns and generic intentions of making adequate public use and urban development plans. How, in what time span, by whom and with what resources are all issues that remain unaddressed.

An important comment refers to the funding strategy (Strategy 10). In a planning document one might expect at least some rough financial projection for the execution of the stated strategies and objectives; instead, it is only mentioned that annual financial planning will be delegated to the UGM, with reference to "the national experience on this subject" (p. 88).

Finally, Strategy 4 (access to the Sanctuary and other infrastructure) deserves particular attention. Besides the planned strategies of managing the existing railway, road, and Inca trail backpackers' access to the HSM, under the general (and generic) objective of "compatibility of transportation infrastructure with conservation purposes" also falls the planned establishment of a helicopter access and a cableway transportation system: an insane project indeed, considering the special condition of Machu Picchu as protected natural area, sanctuary and world heritage site! This proposal responds to a logic other than the conservation, protection and sustainable management of the site, a logic that that is more likely linked to political and private financial interests. Hiding these interests behind the objectives of "facilitating visitor access" or "becoming a visitor attraction", or proposing strategies "to fully rehabilitate the sites affected by the construction of the cableway station" or "to evaluate and supervise the project", does not diminish the huge environmental damage and additional visitor flow pressure that these projects would have caused., In the end, the project was never realized, also because of the strong opposition of the international community.

\section{A More Thorough Effort: Plan Maestro 2005}

The second Master Plan, prepared in 2005, is completely different from the first one, both in content, structure and rhetoric. Eight chapters are spelled out within the 234-page document (see Figure 6 for a list of contents). Comments on this rather lengthy plan follow.

\section{Management of the Plan (Gestión del planeamiento)}

A short historical reconstruction of the site from its discovery onward is provided at the very beginning. The previous Plan (1998-2003) is explicitly 


\begin{tabular}{|c|c|c|}
\hline \multicolumn{2}{|r|}{ FIRST SECTION: THE PLANNING PROCESS } & \multirow{2}{*}{1} \\
\hline & Antecedents & \\
\hline 27 & The Master Plan (1998-2003) and the Management Unit (UGM) & 2 \\
\hline 3 & Guidelines to formulate the new Master Plan & 6 \\
\hline 4 (l) & $\begin{array}{l}\text { UNESCO alerts the world on Machupicchu, the project of rehabilitation of the Vilcanota river and the creation of the } \\
\text { Multisector Committee of World Heritage Sites }\end{array}$ & 7 \\
\hline 5 & Save Machupicchu: The process of the Plan. The character of the Plan: Preliminary studies & 14 \\
\hline $6 / 1$ & Methodological issues for the Master Plan & 14 \\
\hline $7 \mid \mathrm{E}$ & Bibliographical sources for the Master Plan & 26 \\
\hline \multicolumn{2}{|r|}{ SECOND SECTION: CROSS-MANAGEMENT OF THE CULTURAL AND NATURAL HERITAGE } & 27 \\
\hline $1 \mid c$ & Cultural Heritage and territorial achievements of the HSM & 27 \\
\hline 21 & Machupicchu: Patrimonio Mundial Cultural y Natural de la Humanidad & 29 \\
\hline 3 & Cultural Heritage in the Cusco Department & 29 \\
\hline $4 \mathrm{~L}$ & Legislative framework on cultural protection & 30 \\
\hline $\begin{array}{lll} & 1 & -1 \\
\end{array}$ & The organizational system of the HSM & 34 \\
\hline 6 C & Grounds for the institutional development for the strategic management of HSM & 36 \\
\hline $7 \mathrm{~L}$ & Legislative framework on natural protection & 38 \\
\hline \multicolumn{2}{|r|}{ THIRD SECTION: THE SACRED AREA OF MACHUPICCHU } & 41 \\
\hline $1[5$ & Delimitation & 41 \\
\hline $2 A$ & A unique integrated ecosystem in the Amazonic altiplano & 43 \\
\hline 3 E & Basic physical characteristics & 45 \\
\hline $4 \mathrm{E}$ & Ecosystemic characteristics & 51 \\
\hline 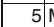 & Main critical environmental issues & 69 \\
\hline $6 \mathrm{~L}$ & Legal ownership and rights on the HSM & 71 \\
\hline 77 & The Archaeological sites & 72 \\
\hline 81 & The Inca City: the different sectors & 83 \\
\hline 97 & The Inca City: pathways and carrying capacity & 93 \\
\hline 101 & Inca Trails and Qapac Nan: sacred itinerary and landscape itinerary & 98 \\
\hline 117 & The site museum & 101 \\
\hline 127 & The meaning of Machupicchu & 103 \\
\hline $13 \mid 7$ & The sacred space-time conception of the Andean world & 107 \\
\hline 147 & The sacred geography of Machupicchhu and the Solar Calendar & 109 \\
\hline $15 \mid$ & Machupicchu, expression of the expansion and adfirmation of the Andean civilization & 113 \\
\hline \multicolumn{2}{|r|}{ FOURTH SECTION: STRATEGY FOR TERRITORIAL MANAGEMENT OF THE HSM } & 115 \\
\hline $1 \mid \mathrm{E}$ & Basic characteristics of the building system & 115 \\
\hline 27 & The economic sub-system & 132 \\
\hline \multicolumn{2}{|r|}{ FIFTH SECTION: PROCESSES AND TRENDS IN THE TERRITORIAL DEVELOPMENT } & 142 \\
\hline $1[5$ & Definition of the areas of territorial development & 143 \\
\hline 21 & Valuation of the areas of territorial development & 150 \\
\hline $3 \mathrm{~F}$ & Processes and trends & 152 \\
\hline \multicolumn{2}{|r|}{ SIXTH SECTION: VISION AND STRATEGIC LINES } & 154 \\
\hline 1 (C & Critical issues and strenghts & 157 \\
\hline 27 & The vision of the Master Plan & 158 \\
\hline 31 & The horizon of the Master Plan & 158 \\
\hline \multicolumn{3}{|c|}{\begin{tabular}{l|l}
4 & Characteristics of the Plan
\end{tabular}} \\
\hline & 4.1 The Master Plan as a management tool & 158 \\
\hline & 4.2 The Master Plan as a consensus tool & 159 \\
\hline & 4.3 The Master Plan as an integration tool & 159 \\
\hline & 4.4 The Andean and Amazonic cosmovision of the native people & 159 \\
\hline & 4.5 Philosophy of the traditional management of the natural and cultural resources & 159 \\
\hline & 4.6 Fundamentals of a common vision & 159 \\
\hline 5 C & Orienting principles and objectives & 159 \\
\hline & 5.1 Orienting Principles & 159 \\
\hline & 5.2 Development Objectives and Strategic Objectives & 160 \\
\hline
\end{tabular}

Figure 6. Plan Maestro 2005: Summary

criticized for its bias toward tourism exploitation, its lack of reference to the sacred nature of the area and its value as a biodiversity park, and the absence of a definition of a maximum number of visitors. UNESCO's arguments for abandoning the logic of the previous Plan led to the proposal of new basic assumptions for the plan. Instead of a "tourist enclave", new dimensions are addressed: the sacred, cultural and natural value of the site 


\begin{tabular}{|c|c|}
\hline 6 Interventions areas, Heritage territorial units and Buffer Zone & 161 \\
\hline 6.1 Intervention areas & 162 \\
\hline 6.2 Heritage territorial units of the HSM & 163 \\
\hline 6.3 Buffer Zone & 164 \\
\hline 7 Strategic Lines & 165 \\
\hline 7.1 Strategic Lines of autenticity and conservation & 165 \\
\hline 7.2 Strategic Lines of territoriality and public use & 190 \\
\hline 7.3 Management Strategic Lines & 204 \\
\hline SEVENTH SECTION: EXECUTING THE PLAN - PROGRAMS AND PROJECTS & 205 \\
\hline 1 Execution conceptual sequence & 205 \\
\hline 2 Financial sustainability and investment resources & 206 \\
\hline 2.1 Characteristics of the financial and economic sustainability & 206 \\
\hline $2.2 \mathrm{~A}$ doable scenario & 208 \\
\hline 2.3 The complementarity & 208 \\
\hline \begin{tabular}{l|l}
3 & Programs and projects for priority investments \\
\end{tabular} & 209 \\
\hline 3.2 Program 01: Autenticity and conservation & 210 \\
\hline 3.2 Program 02: Territoriality and public use & 212 \\
\hline 3.3 Program 03: Management & 213 \\
\hline 4 Investment Programs & 214 \\
\hline 5 Technical specifications - Summary & 221 \\
\hline EIGHTH SECTION: MANAGING THE MASTERPLAN & 225 \\
\hline \begin{tabular}{l|l|l} 
& To adapt and to imprive the Management Unit (UGM) \\
\end{tabular} & 225 \\
\hline 2 The restructuring of INC-Cuscoin function of the Regional Heritage network & 225 \\
\hline 3 Institutional strenghtening of the leadership of HSM - INRENA & 225 \\
\hline 3.1 General Objective & 226 \\
\hline 3.2 Specific objectives & 226 \\
\hline 4 To improve and perfection the management of the Archaeological Park of Machupicchu & 227 \\
\hline 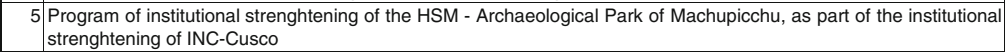 & 227 \\
\hline 5.1 General Objective & 228 \\
\hline 5.2 Specific Objective & 228 \\
\hline \begin{tabular}{l|l}
6 & To adapt the management of Machupicchu to the electronic systems \\
\end{tabular} & 232 \\
\hline
\end{tabular}

Figure 6. continued

and its value for "Andean culture" and national identity. (Natural ecosystems, social ecology, cultural and anthropological ecology are widely-used terms). There is also some reference to organizational issues: the plan quotes literature on networks, organizational ecology, and management, including management of conflicts.

In terms of contents, suffice it to stress some of the major elements that this introductory chapter already defines: a new idea of development, a focus on "eco" solutions in a multitude of senses (cultural, social, anthropological, natural), attention to professional values of preservation and "puesta en valor" from a curatorial point of view, and development investment in research, interpretation, and the museum ${ }^{7}$. References to organizational issues reflect the perception of the area as highly differentiated, with the need to develop adequate degrees of integration (with explicit reference to a ecosystemic view).

In terms of rhetoric, the specific ways in which the arguments are structured deserve attention. Some elements make the plan different from what is normally found, raising an interesting mix of professional and managerial issues: 
- the long historical introduction part shows the will to reconnect the Plan to core issues in archaeology in this area;

- the radical distancing from the previous Plan is rarely found in formal planning (indeed the issue is described as "saving Machu Picchu": p. 14);

- the use of UNESCO criticism as a way to legitimize a new vision is a crucial element, both in terms of contents and process;

- the reference to organizational issues is unusual in a plan written by professionals, though it sometimes echoes a graduate student exercise (it is naïve to some extent);

- even more oddly, there is a specific paragraph dedicated to providing a theoretical basis to "conflict management". Perhaps the writer was aware of one of the hidden issues in the whole agenda, i.e. conflicts between different institutions involved in the area?

\section{Integrated Management of the Cultural and Natural Heritage}

The second chapter provides a description of the cultural and natural components of HSM, the legal basis of its preservation as a world and national heritage. In between, some description of the organizational system of HSM is provided.

In terms of contents, recent developments in heritage legislation are interesting in themselves, as is their links to international changes (international conventions). The regional focus of the legislation is made clear, in forms that are similar to other Roman-code countries. A call for some form of primacy of INC in the Rectoria Cultural is made explicit ${ }^{8}$. The dual nature of bureaucracies that take care of both cultural and natural heritage also emerges, suggesting the basis of uneasy, if not conflictual, relationships between different entities involved in the managing of the HSM.

In terms of rhetoric, there are some interesting elements to notice:

- On the one hand, at a very general level, the similarities between concepts found in different contexts would call for specific ad hoc investigation: the notions of "concurrente legislacion" or the notion of "silencio positivo", difficult to understand for an Anglo-Saxon scholar, can be found in this legal tradition, as for instance in the Italian one. In any case, one would expect a much shorter section on legal issues in countries outside of the Roman-code area.

- More specifically, the legal arguments use in notions that are difficult to translate in English (the word itself "enhancement" is not currently understood): the rhetoric of "puesta en valor" (valorizzazione in Italian;) seems to be accepted, despite the ambiguity that characterizes it. 
Indeed, a research on the genealogy of a similar rhetoric would be interesting in itself (how-despite its ambiguity-this language diffused over time and space).

- Curiously enough, the issue of conflict remains. INC-Cusco is given a leading role ("rectoria cultural") in the development and implementation of the Plan, though within a participatory process including different parties. The issue of "trouble" in the overall governance of change processes is perceived. Whether calling for a leading role is an effective argument is another question: issue of the municipality of Aguas Calientes, never explicitly quoted, is unlikely to be affected by INC-Cusco taking a leading role.

\section{The Sacred Space of Machu Picchu}

This is a very dense, professional chapter. First, following a delimitation/ definition of the "El espacio sagrado de Machu Picchu", the physical/natural characteristics of HSM (geology, geodynamics, biology) are extensively described. The major critical issues are addressed, including the protection of the ecosystem, geodynamic risks, deforestation, poverty and its impact on the environment, and-very briefly, in three lines-the issue of "oversaturation" of visitors". The chapter then discusses complex issues regarding legal rights to the sites is discussed. Among these areissues related to the process of nationalization and the serious controversy with Yale University (see National Geographic, 2009, for an updated view). Second, the features of HSM as archaeological heritage are investigated, with in-depth description of the most important of the 195 archaeological monuments and sites in the territory ${ }^{10}$ and very detailed summary of research on the internal structure of the Inca city of Machu Picchu, the Inca Trails, the relation with the Qhapaq Nan project, and the museum of Machu Picchu. Crucially, the issue of defining the number of visitors to the Inca city is investigated here, and the carrying capacity set at 2500 visitors per day. Third, the meanings of Machu Picchu are extensively analyzed, revisiting a whole century of archaeological and anthropological research: the character of "sacred Andean space-time", the sacred geography of Machu Picchu and the solar calendar, and a final paragraph declaring Machu Picchu as "expression of the expansion and affirmation of Andean civilization" (p. 113) 11 .

In terms of contents, the detailed description in the 71 single-spaced A4 pages of this chapter provides extremely valuable information about the site, information that is barely summarized in its specific and substantive meanings. In addition, the inner complexity of this site clearly emerges, as a sort of "portfolio" of hundreds of individual heritage "assets". Moreover, 
the multidimensional meanings of the site/sites also emerges, including natural heritage along with tangible and intangible cultural heritage (De La Torre and MacLean, 2005). The process itself of defining the maximum number of visitors (2500 per day including guides, plus 500 for the Inca Trails) shows an explicit criticism to the former Plan, marking the distances between new and old decisions. It does so in principle, at least: this number remains problematic in relation to the alleged emphasis on the spiritual meaning of the site. It is hard to enjoy the sacred value of the site when you cannot stop more than ten minutes in any one place, in order to keep traffic fluid. More generally, such mass exploitation seems to be incompatible with a high quality and intense enjoyment of the site ${ }^{12}$.

Despite this partial inconsistency, however, a critical issue is acknowledged: the actual numbers of visitors-particularly in peak time-are under the control of the company running the trains to Machu Picchu, Peru Rail, which was privatized in the previous "era". This is another example of conflicts in the area, not only in terms of "privatizing profits"- transferring a profitable natural monopoly to private hands, without controlling either prices or services-but also losing control over a crucial variable: access and visitors numbers. Whatever the maximum number is set at, a crowd of people clamoring to enter, even in excess of the fixed number, will be hard to resist ${ }^{13}$. Here again, from a managerial point of view, what should be noticed is the difference between orientation, i.e. the need to control the number of visitors, and "getting things done", being able to actually do it, given organizational and institutional conditions.

More in general, the impression is that the Plan itself is years ahead what is actually happening, and what is normally communicated to the visitors. Indeed, a more "conscious" type of visitor would definitely benefit from the establishment of a visitor centre that provides adequate insight prior to the visit. This is another important suggestion that was originally developed by the 2004 World Bank project. Unfortunately, once again, the building that would be the ideal solution-just in front of the entrance of the park-is not available, since it was generously privatized in the Fujimori era as a top class hotel ${ }^{14}$.

Curiously enough, the plan is silent on another topic: the rehabilitation of the hydroelectric plant on the other side of Machu Picchu. This was discussed in the 1998 plan as a means of minimizing impacts to the site. At least in the 1998 plan this concern was acknowledged, while nothing can be found in the 2005 plan.

In terms of rhetoric, the dimension of this chapter is very telling: the style itself-a humanist, a professional at work-is intriguing. Within the plan we find extensive use of bibliographical references and quotations and dialogue with the archeological debate. Different from other experience-and the previous Plan itself-professionals seem to be keen in 
driving the process and the content of the plan, taking the necessary space ( $1 / 3$ of the whole document). Indeed, these first chapters could be provided to the visitor-at least a well educated visitor-for their own informational value.

\section{Strategy of Territorial Management of the SHM Within the Regional Area}

Chapter four addresses the issue of territorial planning, and the linkages between HSM and its context in both positive and negative terms. The transportation infrastructure is investigated, with an interesting historical reconstruction, including economic conditions. A paragraph on the economic "subsystem" is then introduced, which attempts to outline main features of tourism and other local economic activities (mainly agriculture).

In terms of contents, the rich network of sites in the Cusco Region (for those who like the word, truly an archaeological "district") emerges clearly, and is also interesting in terms of organizational implications (both positive and negative). The 30-year contract for operation of the railroad and bus lines to the Inca City are a textbook example of ways of privatizing monopolies. The economic impacts of the development of Machu Picchu for the whole region are investigated as a source of economic development and tourism. Notably, there is the perception that tourism is stagnant during the period of preparation of the Plan. The analysis of the relationship with the local economy-for instance in terms of "Sherpas" and tourism guides - underlines the pervasiveness of impacts.

In terms of rhetoric, the chapter conveys a well-documented (and radical) critique toward past decisions, in particular the exploitation of tourism and the whole logic of privatizing monopoly rents. The language itself is to some extent outdated (the whole language of "subsystem" echoes managerial literature of the 1970s), but the presence of such a chapter is interesting, since archeologists do not often pay attention to these topics in other contexts.

\section{Processes and Trend of Territorial Development}

Here the structure of the whole area is described, distinguishing between different levels (HSM and buffer zone, Valle Sagrado, the whole region). For each of the major areas of development (EOT: "axis of territorial organization", ejes de ordenamiento territorial) an analysis and evaluation of development trends are provided. In terms of contents, the specific elements of development areas can be found here.

In terms of rhetoric, the issue of Aguas Calientes receives a rather marginal role in the plan: although the actual processes of (chaotic) 
development are referred to and critiqued, the actions needed are very weakly defined ${ }^{15}$.

\section{Vision and "Strategic Lines"}

After 153 pages of analysis, the part of the Plan concerning strategic orientation, decision-making and strategies begins with Chapter 6. This is the more "managerial" part of the document. First, comment on critical issues and basic solutions for major themes is offered (e.g. flora, fauna, water, environmental management in general, the Inca City, the Inca Trails). The underlying vision of the Plan is made explicit in a vision statement ${ }^{16}$. Then some technical features are defined: time horizon, uses, guidelines, and goals (Figure 7). After a digression on impacts on different areas, finally the selected strategies (lineamentos estrategicos) are provided (LE1-LE11: Figure 8), and then described in detail.

In terms of contents, the radical distance with the previous Plan is underlined in introducing the new vision: from the exploitation of tourism to the recovery of sacred value (puesta en valor), within a symbiosis of cultural and natural meanings.

In terms of planning technicalities, the time horizon is not clearly defined. Though long term, middle term and short term time spans are quoted, the time horizon itself of the plan is never explicitly stated (we also encountered this ambiguity in discussions). The value of the plan is underlined as a tool for managing, consensus-building, integration, and as a part of the "Andean and Amazonian cosmovision".

Following the statement of basic guidelines, six development goals (Objetivos de Desarrollo, $O D$ ) are "derived from the vision". These include Authenticity and Conservation ("enhancement and conservation of Cultural Heritage; conservation and management of biodiversity; and harmonic development of HSM, territorial units and buffer zones); land use management and public uses ("sustainable territorial management, tourism and cultural management compatible with the HSM"); and management ("management consistent with the character of HSM"). The multidimensional aspects of the site are thus taken simultaneously into account, with a priority given to protection and conservation within a professional perspective. The thirty-four Strategic goals derived from the six OD (see Figure 7) provide a very detailed and dense agenda for the future.

Less clear, in our understanding, the listing of further "lineamentos estrategicos" (LE, Figure 8) which add some ambiguity and redundancy to the above. In any case, while the Strategic Goals (Figure 7) are clearly related to the development goals and vision, this connection is partly lost with the addition of the strange category of "lineamentos estrategicos", which are then further analyzed in almost 30 pages. Curiously enough, in 


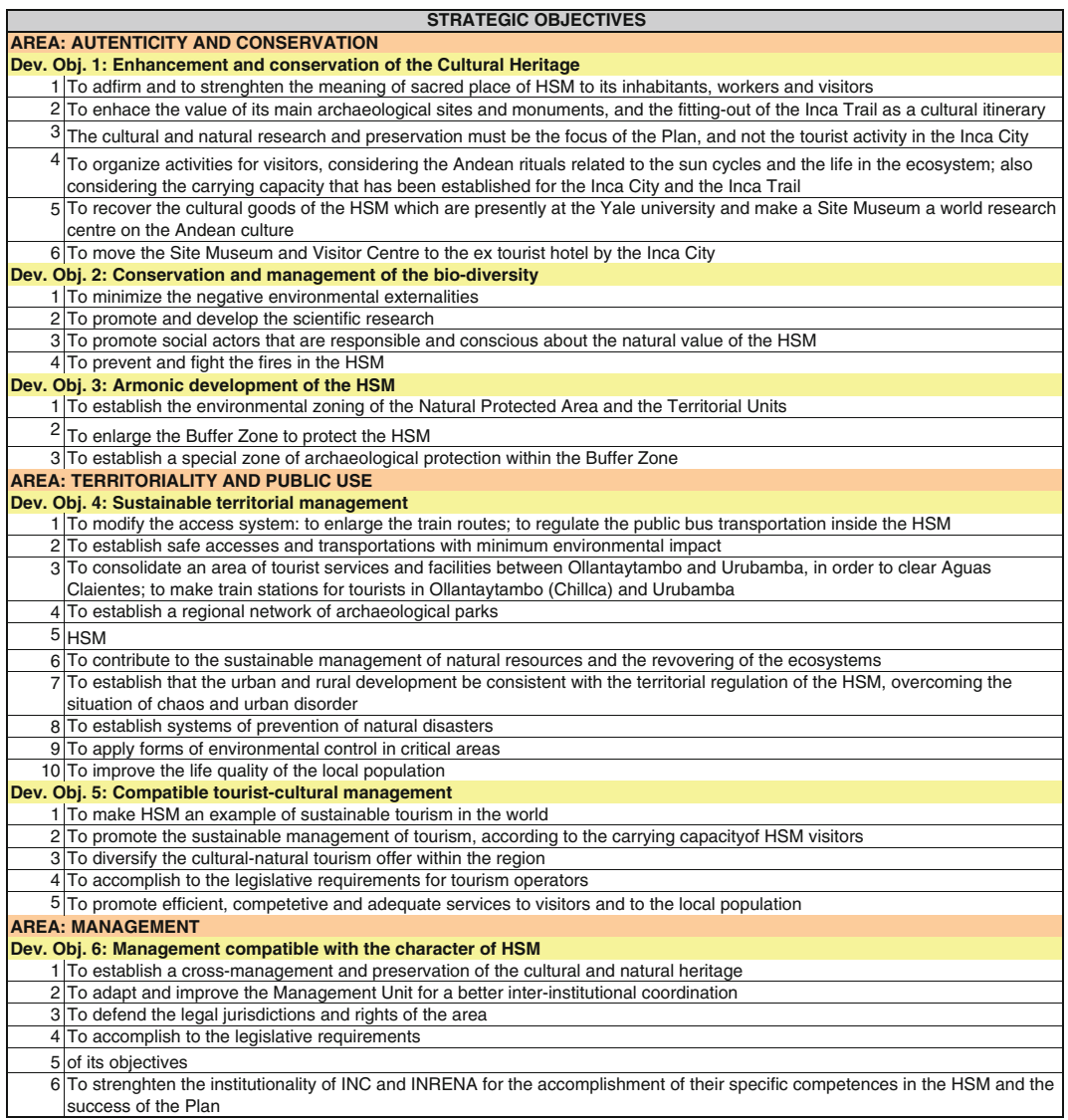

Figure 7. Strategic objectives of Master Plan 2005

the later parts of the Plan, discussion returns to the notion of strategic goals, forgetting the LEs.

In terms of rhetoric, this part of the Plan is the closest to the current managerial mainstream, yet with its own professional pathos. Rather than a standard, mechanistic application of SWOT analysis (or managerial exercises as in the British Museum in 1996 [see Zan 2000]), a more tailored analysis of issues and basic solutions is here provided. Some doubts remain about argumentation strategies when referring to the "lineamentos estrategicos", which lack linkages to the goals set above or the resources allocated later. Furthermore, a common issue when too many targets are listed arises: the twelve lineamentos have different relevance (just seven will get resources later in the Plan, and especially two of them: LE2. Enhancement of the main sites of the HSM and fitting out of Inca Trail as Cultural path; 


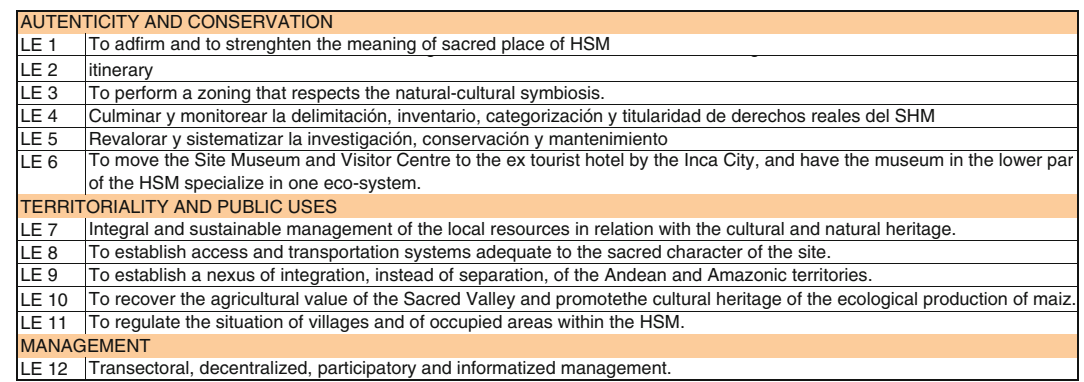

Figure 8. Strategies in Plan Maestro 2005

LE4. Culminate and monitor the delimitation, inventory, categorization and the ownership of right of the HSM). However, no clear ranking or prioritization is made explicit.

Also in terms of rhetoric, it is striking at this point that there is no mention of the problem of Aguas Calientes.

Sequence for the Execution of the Plan and Programs and Projects of Investments

This is a crucial chapter, wherein both a timing of implementation is provided, as well as short but incisive analysis of financial sustainability of the overall plan, followed by a list of programs and projects deriving from the previous step. The list of investment projects is finally defined, with details on expenditures (Figure 9) and timing (Figures 10, 11).

In terms of contents, the timeline defines four major phases (the last for years 6-10) in rather descriptive ways, not linked with more detailed references to programs or projects: "timing" is ambiguous here and hard to define accurately. The sustainability analysis, in sum, finishes with one major point: basically, there are no serious constraints to investment projects, and the whole plan will be self-funded, based on visitor fees ${ }^{17}$.

The whole investment plan-with details of programs, subprograms, projects and subprojects-is indeed shocking, in terms of both dimension and the effort required (to think it, to write it, to read it, but most of all to get it done!) On the whole, 315 million soles (95 million dollars) of projects are identified, described, quantified and planned, based on an enormous amount of work in analysis and project design. A huge, detailed, structured investment plan, totally self-funded: this is a rather unusual situation for heritage anywhere in the world, and is made possible by the internal economics of one of the world's richest sites. 


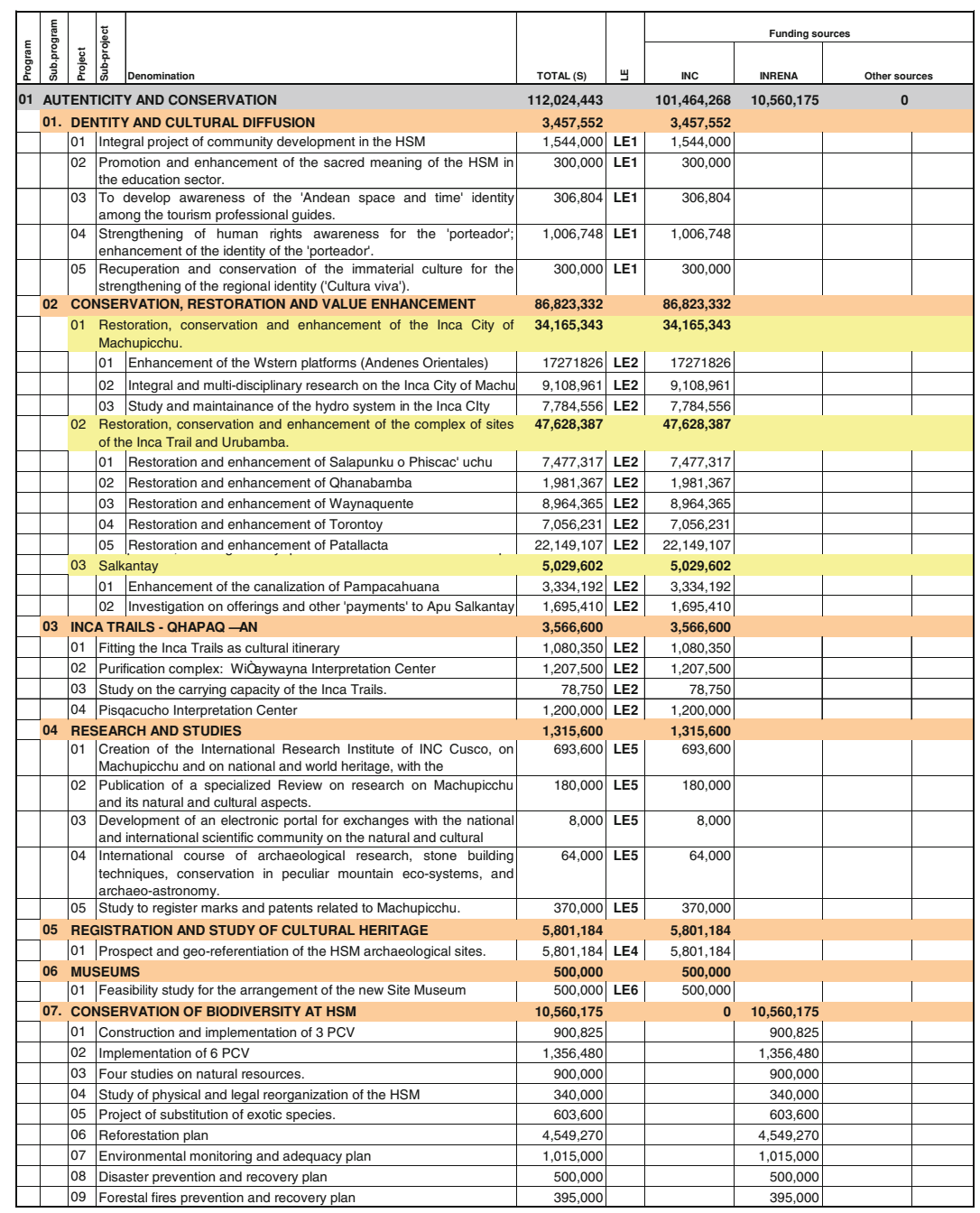

Figure 9. Plan Maestro 2005: Expenditures and sources

In terms of rhetoric, a few elements deserve comment. First, the sustainability analysis occupies only five lines: there is no need for an elegant application of business economics in this case! Furthermore, no special constraint (e.g. lack of money) seems to exist compared to possible investments, with a very unusual situation where there is not a serious conflict between alternative investments, which here simply seem to be ordered over time. 


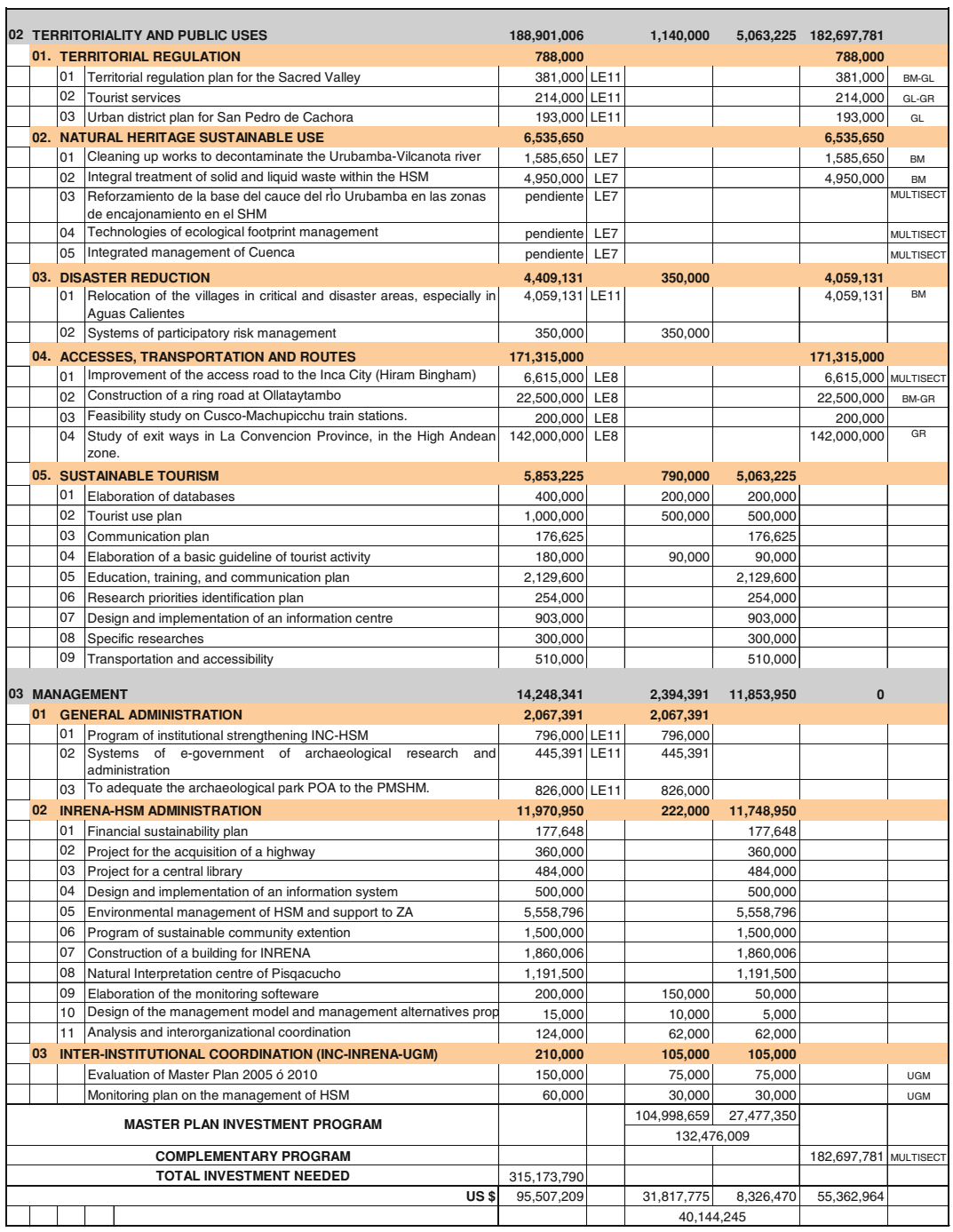

Figure 9. continued

Second, despite the overall consistency of this part in itself and with the previous professional analysis of the sites and their problems, two aspects can be noticed that are likely to create confusion-or at least, they could have helped the reader better focus attention-in this chapter: 


\begin{tabular}{|c|c|c|c|c|c|c|c|}
\hline & & Synthesis & TOTAL (S) & & INC & INRENA & Other \\
\hline \multirow[t]{8}{*}{01} & AUT & ENTICITY AND CONSERVATION & $112,024,443$ & & $101,464,268$ & $10,560,175$ & 0 \\
\hline & 01. & IDENTITY AND CULTURAL DIFFUSION & $3,457,552$ & LE1 & $3,457,552$ & & \\
\hline & 02 & CONSERVATION, RESTORATION AND VALUE ENHANCEMENT & $86,823,332$ & LE2 & $86,823,332$ & & \\
\hline & 03 & INCA TRAILS - QHAPAC-NAN & $3,566,600$ & LE2 & $3,566,600$ & & \\
\hline & 04 & RESEARCH AND STUDIES & $1,315,600$ & LE5 & $1,315,600$ & & \\
\hline & 05 & REGISTRATION AND STUDY OF CULTURAL HERITAGE & $5,801,184$ & LE4 & $5,801,184$ & & \\
\hline & 06 & MUSEUMS & 500,000 & LE6 & 500,000 & & \\
\hline & 07. & CONSERVATION OF BIODIVERSITY AT HSM & $10,560,175$ & - & 이 & $10,560,175$ & \\
\hline \multirow[t]{6}{*}{02} & TER & ZRITORIALITY AND PUBLIC USES & $188,901,006$ & & $1,140,000$ & $5,063,225$ & $182,697,781$ \\
\hline & 01. & TERRITORIAL REGULATION & 788,000 & LE11 & & & 788,000 \\
\hline & 02. & NATURAL HERITAGE SUSTAINABLE USE & $6,535,650$ & LE7 & & & $6,535,650$ \\
\hline & 03. & DISASTER REDUCTION & $4,409,131$ & LE11 & 350,000 & & $4,059,131$ \\
\hline & 04. & ACCESSES, TRANSPORTATION AND ROUTES & $171,315,000$ & LE8 & & & $171,315,000$ \\
\hline & 05. & SUSTAINABLE TOURISM & $5,853,225$ & - & 790,000 & $5,063,225$ & \\
\hline \multirow[t]{4}{*}{03.} & MAN & VAGEMENT & $14,248,341$ & & $2,394,391$ & $11,853,950$ & 0 \\
\hline & 01 & GENERAL ADMINISTRATION & $2,067,391$ & LE11 & $2,067,391$ & & \\
\hline & 02 & INRENA-HSM ADMINISTRATION & $11,970,950$ & -1 & 222,000 & $11,748,950$ & \\
\hline & 03 & INTER-INSTITUTIONAL COORDINATION (INC-INRENA-UGM) & 210,000 & - & 105,000 & 105,000 & \\
\hline \multirow{2}{*}{\multicolumn{3}{|c|}{ MASTER PLAN INVESTMENT PROGRAM }} & & & $104,998,659$ & $27,477,350$ & \\
\hline & & & & & \multicolumn{2}{|c|}{$132,476,009$} & \\
\hline \multicolumn{3}{|r|}{ COMPLEMENTARY PROGRAM } & & & & & $182,697,781$ \\
\hline \multicolumn{3}{|r|}{ TOTAL INVESTMENT NEEDED } & $315,173,790$ & & & & \\
\hline \multirow{2}{*}{\multicolumn{3}{|c|}{ US \$ }} & $95,507,209$ & & $31,817,775$ & $8,326,470$ & $55,362,964$ \\
\hline & & & & & \multicolumn{2}{|c|}{$40,144,245$} & \\
\hline
\end{tabular}

Figure 9. continued

- The investment plan (Figure 9) refers to a "virtual" entity more than to a specific organization: it is the amount of money (and projects) to be run in HSM, without the existence of an institutional entity "HSM" as such. Indeed, the plan has to define sources (and actions) that should be provided by various entities: INC, Inrena, the World Bank, and local government (see the last columns in Figure 10a). The intrinsic institutional fragmentation of the Peruvian administrative system, and the need to run the whole as - indeed-a whole (what in management terms would be referred to as a unitary governance structure) will give rise to a conflictual and ambiguous dialogue with UNESCO and the World Bank about the role of the Management Unit for Machu Picchu (UGM).

- The investment plan itself (and indeed all the previous chapters on strategies and goals) seems to lack to some extent a notion of priority, at least in terms of addressing attention. Looking at figures, and considering just investments in the charge of INC Cusco, one could argue that there are basically two major projects (subprogram 02, projects 01 and 02 ) of 35-45 million soles; the rest are surely important projects in terms of contents, but much more routine from a project management point of view (3-6 million or less). In terms of timing, an examination of Figure 11 addresses the hidden time horizon of the investment plan: one or two years of startup, followed by a "normal" level of expenditures for about four years, and then a very marginal role for investment during the last five years. In this sense, in substantive terms, the plan looks more like a five-year than a ten-year plan. 


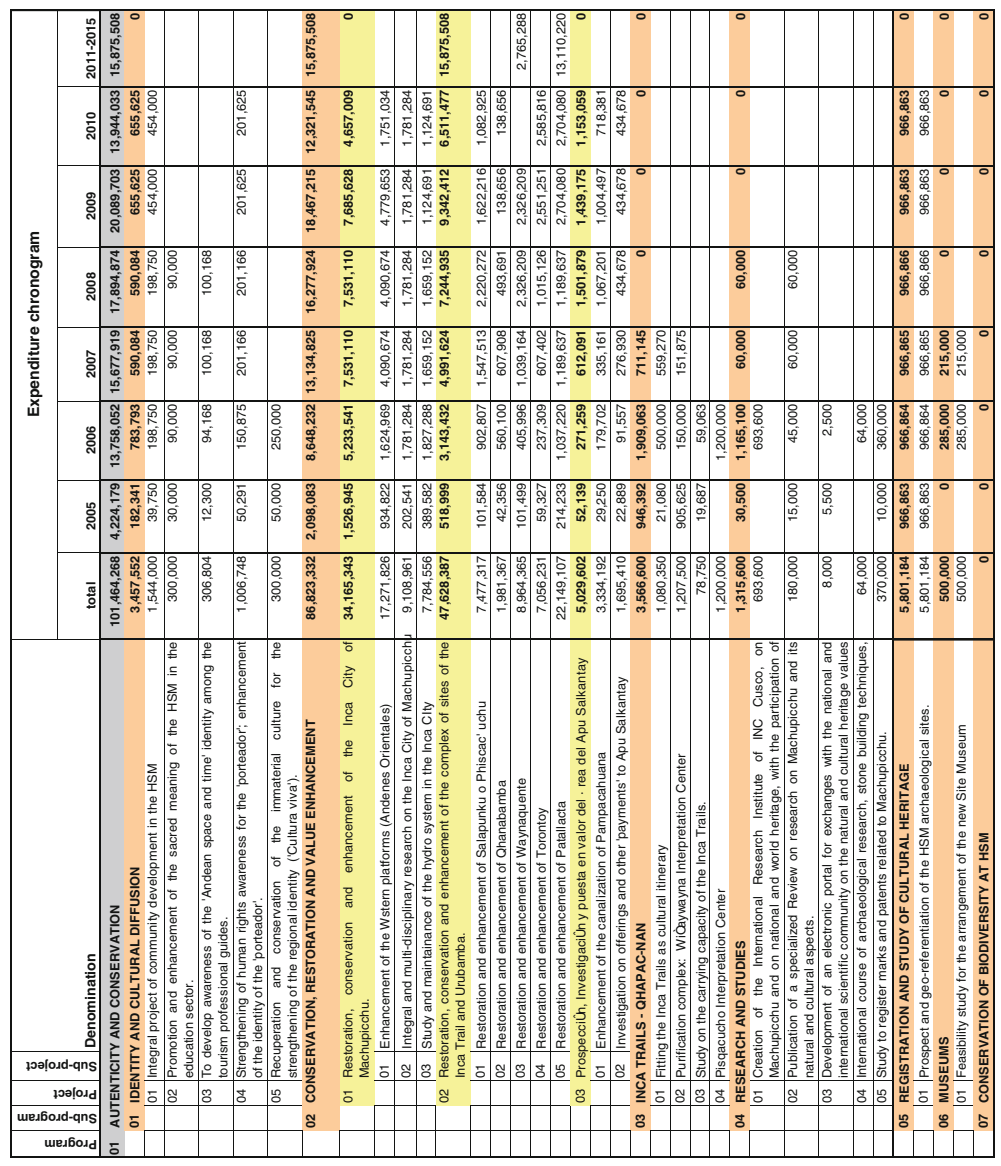




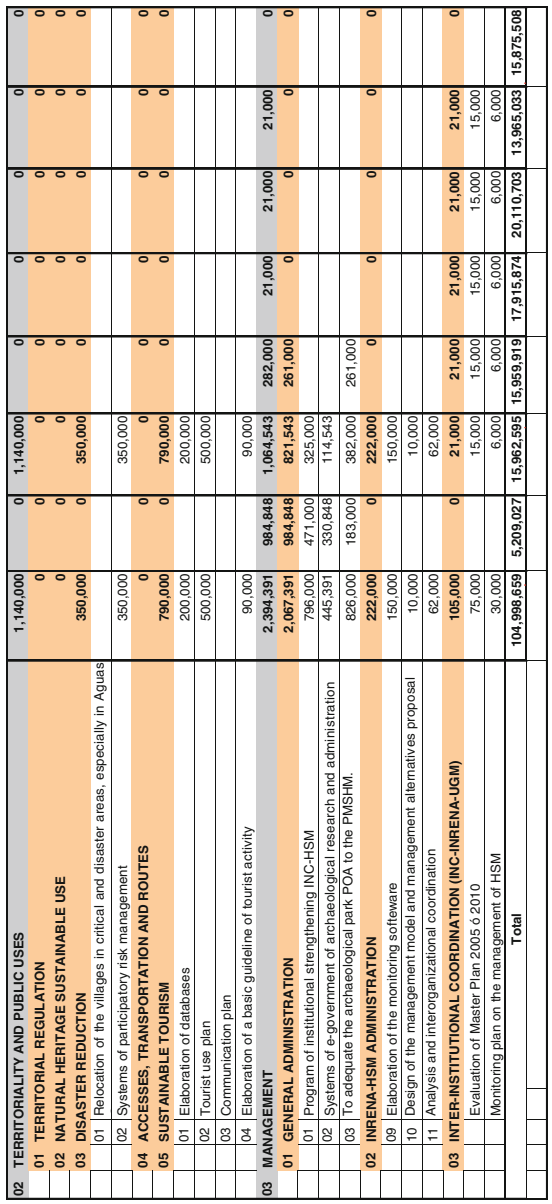

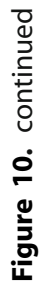




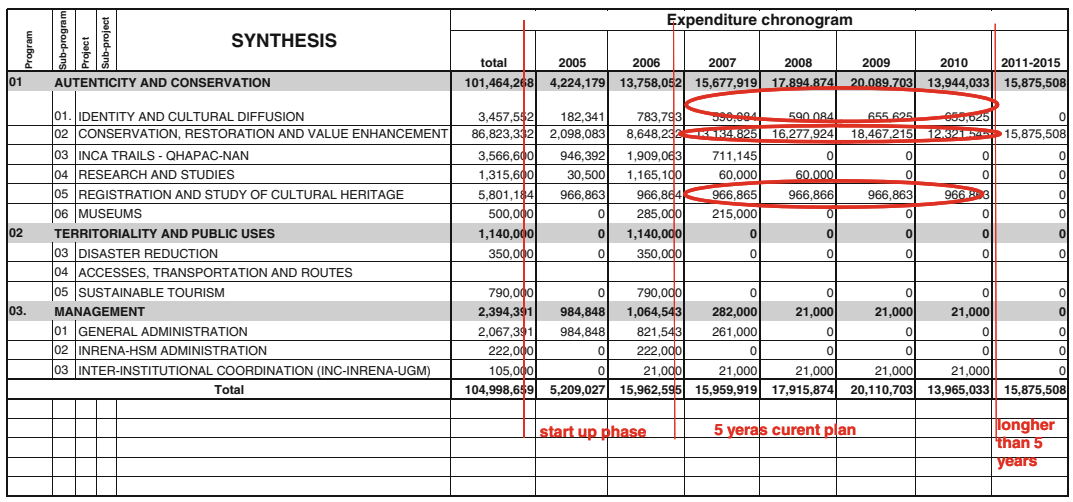

Figure 11. Plan Maestro 2005: three phases

\section{Management of the HSM Master Plan}

The last chapter addresses organizational conditions that are needed to better implement the plan. The need to change the management pattern is explicitly stated. The need to improve UGM is then investigated, with implications for on INC-Inrena relations and the "institutional empowerment ("fortalecimiento institucional") of various entities.

In terms of contents, one could argue that at least the issue of "empowering" the unitary management of HSM is addressed: whether the solution is adequate as a way to overcome institutional fragmentation is still controversial. Interesting enough, also the need to empower INC Cusco itself is addressed.

In terms of rhetoric, in general the language used in this chapter is more addressed to procedural than to substantive issues, and because of this is a bit more abstract or "general". In any case, Aguas Calientes is still missing from the picture. This is perhaps the major weakness (or, one could say, the most serious weakness) of the Plan, if not a type of "ghost".

\section{Discussion}

If management is mainly a matter of addressing attention, the analysis of the two Master Plans from a management studies point of view is a unique occasion to study where attention has been addressed to in Machu Picchu over time, i.e. how a complex site like Machu Picchu is managed, and how managerial practices and discourses have changed. Assessing how plans change is a first issue. Evaluating actual changes in the management of the site is however a different issue. 


\section{Changing Plans}

To sum up, we will here review and compare some of the most salient aspects of each Plan in order to capture changes in the management of Machu Picchu and in the underlying managerial and organizational culture.

Plan Maestro 1998, a Summary

- Origin: the Plan Maestro 1998 originated as a UNESCO requirement, pushed by the international community and realized by a small task force under the supervision of INC and especially Inrena on behalf of the Peruvian Government.

- Time horizon: supposedly it should have been a long-range (10-year) plan, but it was definitely aborted in 2003.

- Structure: out of 330 pages, 90 pages (less than 30\% of the Plan) are dedicated to the planning document and 240 pages are dedicated to several descriptive attachments. But even in the 90 pages of the planning document part, very little has to do with actual planning: section 1,2 and 3 of the plan are all in different ways descriptive sections, rather than planning, and section 4 is a list of planning intentions that remain at a very general level.

- Style and rhetoric: it is a descriptive (indeed quite generic and superficial) and analytical document, full of a "rhetoric of objectives" and of typical formal planning features and jargon. It opens up by announcing goals in the first section, continues with a SWOT analysis, and then with a cascade as follows: general 10-year vision $\rightarrow$ strategies $\rightarrow$ specific objectives $\rightarrow$ "strategic lines"). The document is also full of a "rhetoric of sustainability", with continuous asserted tradeoffs between tourism exploitation and respect for conservation at the site, which is never treated in numerical terms.

- Contents: the Plan highlights problems and weaknesses affecting the HSM, as well as its competitive resources, but lacks any strategic and organizational design. No projection of time, resources, or actions is outlined in any way, and no actual decisions on the coordination and control of activities are made. Probably the only concrete contribution concerning organizational aspects is the call for the establishment of a Management Unit (UGM) - yet it fails to provide an organizational design or a tentative resource allocation model for the realization and running of the unit. Moreover, it is striking that in a pretty generic Plan that fails to address specifics, the only projects receiving more specificity concern the infrastructure for access to the Sanctuary: 
the helicopter and the cableway projects, railway, roads and Inca Trail access, and the planned construction of a hydroelectric plant inside the natural park!

- Addressing attention. Priority is given to (a) the concept of the protected natural area and the related legislation and principles (derived from the Peruvian tradition, predating UNESCO's intervention in the HSM); (b) issues of social and economic development (and the relevance of "sustainable" tourism exploitation); and (c) regulation of urban and territorial development (including the problem of Aguas Calientes). By contrast, only minor explicit attention is given to (i) the UNESCO Convention and its principles; (ii) the conservation and restoration of the archaeological heritage per se, beside its value as a component of the surrounding environment (it is not clear if this "naturalistic bias" is due to the major influence of INRENA in the definition of the Plan, or rather if it derives from an Andean conception of actual indissolubility of natural and historical-cultural aspects); (iii) conservation and research in general; (iv) managerial solutions: the Plan conceptually isolates several inter-institutional and administrative problems, but it is far from suggesting solutions and action lines.

\section{Plan Maestro 2005, a Summary}

- Origin: the Plan originated from the failure of the previous one and of the UGM, in the context of strong criticism and the UNESCO's insistence on the adoption of a new-and better-management plan. Moreover, it was formulated in a different administrative/political context, in a period of public sector transformation after the Fujimori era, when the country was moving towards a new culture of transparency, planning and control of resources and actions. The process of formulation responded to a logic of participatory planning, involving a large and composite team of professionals and representatives.

- Time horizon: this Plan too is meant to be a long-range (10 year) plan and is at present under implementation. However, the plan is incrementally defined: overarching goals and strategies are set, but the detail of the planned activities and expenditures gradually decreases in the medium and longer term, consistently with an incremental approach to the development of a strategy.

- Structure and contents: the Plan is articulated in 8 chapters (234 pages + attachments), of which chapters $1-5$ ( $1 / 3$ of the document) concern a reconstruction of the cultural, historical, political, and legis- 
lative context of Machu Picchu, while only later-and based on this first part-chapters 6-8 deal with the definition of a vision, setting goals and formulating strategies.

- Style and rhetoric: the document alternates between the humanist approach of the first part and the more common managerial discourse of the second part. This change in the style reflects the different purposes of the two components of the Plan: (a) to deeply describe and understand the inner essence and complexity of the site (its cultural, natural, but also sacred nature; its past but also living culture; the intertwining of different interests and powers); (b) to derive goals and strategies and to plan actions, resources and timing to achieve them, in order to "get things done". In any case, a form of dialogue between these two dimensions takes place within the plan.

- Addressing attention. In this Plan prior attention is given to (a) the archaeological/professional dimension; (b) the enhancement of the sacred value of the site, besides its world-recognized cultural and natural value; (b) the UNESCO normative framework, besides the national legislation; (c) organizational issues and, particularly, the inter-institutional coordination. Minor attention is given to issues concerning tourism exploitation and to the economic value of the site. Interestingly, no attention at all is given to the problem of Aguas Calientes.

\section{Comparing the Plans}

Much has changed throughout years. Beside-and perhaps in part also because of-macro changes in the cultural/political context (the end of an era ruled by corruption and the beginning of the "modernization" of the State), the role of Plans seems to have deeply transformed. The change goes from the use of the Plan as a bureaucratic or political requirement to its use as a managerial instrument, i.e. a tool to address attention, set priorities, and coordinate by regulating the flow of actions and decisions and giving them a structure.

The importance attributed to the plan has changed: it is significant in this regard the amount of people and the whole organizing process that led to the establishment of the second Plan, while in 1998 the Plan Maestro was compelled by UNESCO and realized in a top-down way by a small team of four external consultants with scant involvement of professionals from the institutions that manage the site.

In its structure, contents and rhetoric, the Plan Maestro 1998 presents typical features of formal strategic planning documents. On the other hand for the Plan Maestro 2005, the formal planning/goal-setting part does not derive from a static, ahistorical, acontextual analysis (the conventional 
analysis of gaps between an extant situation and a ideal/target situation, in terms of fitting between internal resources and external requirements). Both the external environment and the Sanctuary itself are presented through a historical and cultural reconstruction of the different logics of action and the different interests and conflicts involved. Hence in this case the Plan seems to be a locus of programming actions and decisions (the last three chapters), on the base of a deep, prior understanding of the historical, process-informed, contextual meaning and specificities of a site (the first five chapters), relevant from a professional point of view.

The Plan Maestro 1998 seems a "rhetorical exercise", rather than an actual management plan. Indeed, criticisms coming from the international community (UNESCO and Icomos) have been very severe on the genericism and lack of operational character of the Plan, also complaining that the strategic planning contents of the document hid implicit strategies and goals (in particular, speculative and political interests concerning the exploitation of tourism flows, as in the cableway project.

Compared to the its predecessor, the Plan Maestro 2005 can be considered as an operational management tool, given that-despite a few inconsistencies - the hierarchy of objectives, strategies and specific projects is coupled in its detailed tables with timing, allocation of resources, and indication of the funding source at each level. Goals and actions are represented in their numerical implication for the future: expenditures, investments, funds. Moreover, as we directly observed on site, the Plan Maestro 2005 is a strong point of reference in the daily practices of administrative, but also professional personnel of HSM (archaeologists, architects, anthropologists). The Plan is widely used as the framework through which they organize their activities, coordinate with other processes and at the same time make sense of their contributions in a logic of integrated action.

Compared to more general situations that can be found in heritage management, an interesting element characterizes the 2005 Plan, however. The role of accounting in this picture appears strange, if not paradoxical. The whole development of SNIP, as we have seen, has the unintended consequence to lead to financial statements of the individual entity (e.g. INCCusco) which are largely meaningless. Calculation practices are introduced, and forms of responsibility at the level of projects as well, at the cost of losing transparency at the level of normal accounting information. Indeed, the data provided in this article cannot be elaborated by an external analyst: and the World Bank itself, during the project of Vilcanota recovery, was not aware of similar information. In this sense, the struggle against corruption has a very unusual impact, reducing transparency of normal financial reports. 


\section{Plans and Actual Change: a Difficult Issue to Assess}

Given our background as management scholars we are particularly interested in understanding how plans intervene in the context of change at HSM, as an element in the evolution of discourse about managing the whole area (the manejo). As the analysis above rather clearly shows, there were two plans, and they were radically different both in contents and in rhetoric. Moreover, plans were the organizational locus in which different discourses were articulated, presented, and supported.

As usual in management, the question is to what extent plans (in a way or the other) have an effect at all; in this case, how different plans are able to make change possible. If the second plan is radically different from the first one, what matters in the end is whether reality at Machu Picchu is now different than before.

Here a research question arises, in analyzing actual impacts, taking into account the complexity of decision making processes in both its cognitive and political dimensions, following one of the most interesting debates on organization within management studies. In principle, the failure to effectively address crucial issues may be an explanation in itself of the relative modest impact of the Plan compared to what one would expect. Three different elements can interfere at this level in terms of making change possible or not (focusing in particular to changes fostered by the 2005 Plan compared to the previous one).

First, there is the issue of the overall internal consistency of the plan. Though most of the 2005 plan clearly (often explicitly) takes into account suggestions and warnings by the international community, two elements represent a sort of weakness in the overall picture, if not inconsistencies: the total lack or reference to the issue of Aguas Calientes, one of the major preoccupations of UNESCO; and the generous defininition of the number of maximum visitors per day, 2500 together with the actual lack of mechanisms to implement even this standard. If already at this level of analysis similar crucial issues are not adequately represented, it is hard to expect that actual change will take place accordingly to the international community wishes on these two issues.

Second, there is the issue of the "processual" nature of a plan. The plan is not an act in itself: it addresses attention, mobilizes resources and actions. All this takes time. Here in particular the whole planning process was requiring time to prepare details for projects (inversiones) - according to the SNIP procedures-and later getting permissions and starting operations. Most investments activated by the plan are still in progress (few of them are actually in progress). This is a normal issue, and even the best plan that addressed attention of people inside the organization would still appear to have little impact for an external observer (e.g. the visitor). 
Third, the best plan, implemented on time, might still have only minor impacts depending on the reactions of other actors with different interests and views. More explicitly, vested interests in the area and/or illegal behavior could act to effectively resist the change called for by the plan (e.g. economic interest in exploiting tourism in Aguas Calientes; illegal guides; elusion of norms inside the park; maximizing train ticket sales). Monitoring the actual impacts of plans is one of the most difficult aspects of planning. Managing vested interests and illegal behaviors is a particularly delicate issue, indeed! The lack of well-established monitoring tools-explicitly set up in the planning process-makes it even harder. (Indeed in the presence of a robust monitoring framework even this article would have been easier to write, and perhaps less interesting to read).

\section{Concluding Remarks}

Understanding change would require mapping the most important elements that are driving the overall process. Here more than elsewhere, the action of internal actors in changes affecting the manejo of HRS is deeply linked with more general external dynamics and phenomena, such as the transformation of Peru's national political system and the role of the international community.

- The transformation at the national level plays a crucial role here: the new climate after the Fujimori period, the attention to archaeological issues by the previous first lady (who was sponsoring the whole Qhapaq Nan project), the whole restructuring of public expenditure procedures, decentralization in general and the autonomy of INC-Cusco in particular, and the SNIP. It would be difficult to understand what is happening in Machu Picchu without understanding the profound change in the context. This provides a further example of a crucial element in the transformation of heritage: changes in professional issues - in the management of an archaeological site-are deeply intertwined with more general trajectories of change at the general administrative level.

- The international community ("public opinion" in general, or more in particular the role of intentional agencies such as UNESCO and World Bank) also played a central role. Interesting enough, this impact took place at different levels, which may be interesting to examine separately. First, there is an overall impact in terms of general policy guidelines (the plan calls for a more curatorial/ecological kind of attitude as a whole). Second, there is an impact at the substantive level referring to specific solutions (e.g. fighting the idea of 
the cableway). Third, there is a role in terms of methodologies that are used and transferred.

As management scholars our focus tends to lie at an intermediate level between general policies and professional substantive views. While UNESCO clearly does its job by criticizing the lack of actual adequate results, in our perspective assessing the processes of change in addressing attention is somehow a softer aspect. A few questions can perhaps be pointed out from this point of view. Archaeologists in Machu Picchu (and Cusco) not only are in favor of UNESCO, but they all seem to trust in the Plan Maestro 2005. At all the meetings we had, people were coming with their own copy of the Plan, and were constantly referring to it: a sort of symbol of "archaeological pride" recovering after Fujimori's commercial exploitation of the site. From the point of view of the Press, and how the Press refers to UNESCO's positions, a more detailed acknowledgement of differences of behavior/attitude would be worthwhile. What is missing is a more specific assessment of responsibilities and achievements: HSM, with all its problems, cannot be said to be "badly managed". The problem and the responsibilities are related to institutional fragmentation (i.e. the authority of Aguas Calientes within a protected area and the inconsistent attitude of tourism agencies (and the ministry?) who still aim at maximizing flows and revenues).

This is not only a question of recognizing the efforts of those that fight together "with" the international call for preservation. Identifying friends and enemies, and acknowledging respective efforts and responsibilities is a further element for motivating people and mobilizing actions. It is also a question of addressing main issues that would have needed a more aware attitude from the very beginning. The whole ambiguity of UGM (the management unit), and the confusion between a unitary governance structure and a mere coordinating entity with no direct power or budget would have been different in the presence of more radical effor to overcome institutional fragmentation ${ }^{18}$.

Finally, actual impacts would have been clearer-and actions themselves easier-in the presence of monitoring frameworks, whose absence represents perhaps the main weakness of planning practice-not just at Machu Picchu, but more in general.

\section{Acknowledgments}

Several people have been fundamental in allowing this paper to be completed. We would like to thank especially Arch. Jorge Zegarra Balcazar, at that time INC-Cusco Director, Fernando Astete, Director of the Historical 
Sanctuary of Machupicchu, Arch. Jorge Prado Tisoc, Chief of the International Cooperation Office of INC-Cusco, and to the whole staff of INCCusco and HSM for welcoming us and providing us with rich documentation on the institution during our visit to Peru in 2008. Many thanks also to Roberto Chavez for his precious suggestions for our research. The authors also wish to thank one of the anonymous referees for the generous advice and assistance in revising this article for publication.

\section{Notes}

1. UNESCO documents are full of criticism to this situation: "Machu Picchu Village (Aguas Calientes) has undergone expansion outside the limits authorized by INRENA; including the erection of buildings in the bed of the River Vilcanota, and the construction of buildings with more than three storeys without the necessary permits. These facts have caused concern on the part of INRENA regarding the absence of proper procedures, a lapse in governance, the increased risk of flooding and landslides, and the rise in environmental and landscape damage" (UNESCO 2007:27).

2. The appendixes include: a review of the relevant legislation, a brief institutional presentation of INC and INRENA, a long historical and descriptive digression of the HSM, a list of the entities that took part to the workshops for the formulation of the Plan, a long and detailed diagnostic of the zones of the Sanctuary, including tables and pictures.

3. Decreto Supremo 021/1981 AA, in which the HSM was declared a "protected natural area".

4. E.g. "a good institutional basis in terms of expertise and competences" as a strength and, at the same time, "poorly trained professionals" as a weakness (pp. 22, 26); or "will and awareness of the need to collaborate among different institutions" as a strength and, at the same time, strong critiques of the existing inter-institutional conflicts among the weaknesses (ibidem).

5. E.g. among the strengths: "there are the conditions for positive impacts of the management of the HSM on the cultural and natural aspects", pp. 22-23.

6. "[La] administración gerencial ediciente e adecuada", "[elaborará] un plan operativo de emergencia y planes operatives bianuales", "identificará y desarrollará lineas de acción para la recuperación y conservación del Santuario", p. 82.

7. "El riesgo y el peligro principal de afectación irremediable del SHM, en su ámbito de intervención directa y de desarrollo compartido, esta en las tendencias inerciales del enclave turístico que destruye este espacio sagrado para transformarlo en zona de entretenimiento adscrita en forma subordinada a la globalización homogenizante etnocéntrica occidental. Esta inercia afecta la identidad que sustenta un bien, que es por sobre todo un recurso único y no renovable. Si continúa la inercia del enclave turístico afectaría irremediable- 
mente su autenticidad, y llevaría a una crisis ecológica ambiental del eco sistema complejo y frágil del SHM." (p. 16).

8. "Complementando nuestra referencia anterior sobre el "urbanismo cultural", diremos también que la distribución de competencias exclusivas y concurrentes en materia cultural no significa que cada sector o entidad pública realiza las acciones o proyectos que "mejor le parezca", pues la competencia y tutela cultural ordena las distintas intervenciones mediante una Rectoría Cultural que ha sido atribuida a favor del Instituto Nacional de Cultura" (PM, p. 33).

9. "Existe una sobresaturación de presencia humana en algunas zonas del SHM. Esta sobresaturación impacta de diversas maneras en el medio ambiente, afectando sus equilibrios básicos y acentuando un deterioro sistémico": this is the complete paragraph 5.5, Sobresaturación de visitantes por turismo.

10. In addition to the Inca city of Machu Picchu itself some of the most important sites are: El centro urbano de Patallaqta, Huiñayhuayna, Choquesuysuy, Intipata y otros hitos; Núcleos de vivienda o poblados; Terrazas de cultivo; Obras hidráulicas; Obras viales y caminos; Centros ceremoniales; Contextos funerarios; Canteras y minas.

11. The starting of this decsription is worth quoting: "Luego, la avalancha de un sobre uso turístico, especialmente desde la segunda década del siglo XX, pretende reducirlo a centro de atracción global, descontextualizado, expropiado de sus significados sagrados, aislado de su población originaria, lo que ocasionaría su colapso luego de unas cuantas décadas de sobre uso y desequilibrio entre lo natural y lo construido" (p. 103).

12. The daily capacity itself can lead up to annual capacity of 912,500 visitors, i.e. a bigger projection than the actual figure in these recent years, even considering the doubling since 2004 .

13. As seen, in the 1998 Plan there was an idea of building a cableway to increase the tourists flow. In addition, there was a debate on the possibility of opening the sites over three working shifts for $24 \mathrm{~h}$ a day, with artificial illumination of the site, overlooking the terrible environmental impact of such a solution.

14. The price per room of the Machu Picchu Sanctuary Lodge is about 900 US \$, but with additional services could easily reach 1,700 \$ per night (http://www.sanctuarylodgehotel.com/web/omac/machu_picchu.jsp, lastly consulted on January 18, 2011).

15. There just a single point in both Figure 7 (see OD-4 point 3) and Figure 9 (Territorialidad y uso publico, point 03).

16. "El SHM es un área natural-cultural protegida por el Estado, lugar de acceso al espacio-tiempo andino sagrado, de identidad socio cultural regional y nacional, eje de la red de parques arqueológicos y conformante del sistema nacional de áreas naturales protegidas, centro dinámico del desarrollo sostenible local, regional y nacional, de sabidurías y de conocimientos en la gestión territorial andina, con una gestión transectorial basada en los valores de conservación patrimonial y de la diversidad biológica, con rectoría y tutela cultural, con competencias definidas y sustentabilidad financiera, y participación de los actores sociales" (p. 158). 
17. "Conceptualizamos a la sostenibilidad financiera en el SHM como la suficiencia para enfrentar las propuestas de su manejo establecidas en los diferentes instrumentos de planificación. El SHM no esta afectado por alguna dependencia financiera externa, porque se autofinancia, sin embargo, la sostenibilidad en el SHM significa establecer mecanismos para la maximización en la generación de sus recursos propios" (p. 207).

18. To what extent such a preference toward weak institutional solutions underlines the call for a new World Heritage Committee (Regalado-Perzua and Arias-Valencia 2006) as a mere second-level coordinating units, or as a radically new organization that will overcome/merge existing ones, is not totally out of ambiguity. Of course we would share the latter.

\section{References cited}

APEC.

2007. Peru: Developments in Public Sector Governance. In APEC Economic Policy Report, pp.103-106. http://www.apec.org/Groups/ /media/Files/ Groups/EC/07_ec_AEP_Fnl.ashx.

Burger, R.L., and L.C. Salazar (editors)

2004. Machu Picchu: Unveiling the Mystery of the Incas. Yale Univ. Press, New Haven.

de La Torre, M., and M.G.H. MacLean

2005. Heritage Values in Site Management: Four Case Studies. Getty Publications, Los Angeles.

Friesner, T.

2011. History of SWOT Analysis. http://www.marketingteacher.com/swot/historyof-swot.html. Lastly consulted on January 18, 2011.

Giugale, M.M., V. Fretes-Cibils, and J. Newman

2006. An Opportunity for a Different Peru. Porperous, Equitable, and Governable. The World Bank, Washington DC.

Higueras, A.

2008. Cultural Heritage Management in Peru: Current and Future Challenges. In Handbook of South American Archaeology, edited by H. Silverman, and H.I. William. Springer, New York, pp. 1073-1088.

Learned, E.P., C.R. Christiansen, K. Andrews, and W.D. Guth

1969. Business Policy, Text and Cases, Irwin. Homewood, IL.

March, J.G.

1988. Decisions and Organizations. Blackwell, Oxford. 
Martorell Carreño, A.

2004. Análisis Crítico del Plan Maestro de Machu Picchu, 1998. In Propuestas para una Planificación Proactiva en in Bien del Patrimonio Mundial Cultural Y Natural, Icomos Perú.

Mintzberg, $\mathrm{H}$.

1994. The Rise and Fall of Strategic Planning. The Free Press, New York.

1978. Patterns in Strategy Formation. Management Science 24(9):934-948.

National Geographic.

2009. Video: Yale Agrees to Return Machu Picchu Artifacts, Saturday, January 24, http://news.nationalgeographic.com/news/2007/09/070920-inca-video. html.

Normann, R.

1977. Management for Growth. Wiley, Chichester.

Pettigrew, A.M. (editor)

1987. The management of Strategic Change. Blackwell, Oxford.

Regalado-Perzua, O., and J. Arias-Valencia

2006. Sustainable Development In tourism: A Proposition for Machu Picchu, Peru. In Managing World Heritage Sites, edited by A. Leask, and A. Fyall. Butterworth-Heinemann, Oxford.

Reinhard, J.

2007. Machu Picchu: Exploring an Ancient Andean Center. The Cotsen Institute of Archaeology, UCLA, Los Angeles.

Ringbeck, B.

2008. Management Plans for World Heritage Sites. German Commission for UNESCO.

Silverman, $\mathrm{H}$.

2006. Cultural Resource Management and Heritage Stewardship in Peru. The Journal of Heritage Stewardship 3(2):57-72.

Simon, H.A.

1947. Administrative Behavior. McMillan, New York.

1991. Bounded Rationality and Organizational Learning. Organization Science 2(1):125-134.

\section{UNESCO.}

2007. The State of Conservation of the World Heritage site: The Historic Sanctuary of Machu Picchu, Peru. Report of the UNESCO-IUCN-ICOMOS Mission to Machu Picchu, Peru, 22 April to 30 April 2007. 
Zan, L.

1990. Looking for Theories in Strategy Studies. Scandinavian Journal of Management 6(2):89-108.

2000. Management and the British Museum. Museum Management and Curatorship 18(3):221-270.

2006. Managerial Rhetoric and Arts Organizations. Palgrave-Macmillan, Basingstoke. 